University of Nebraska - Lincoln

DigitalCommons@University of Nebraska - Lincoln

Papers in the Earth and Atmospheric Sciences

Earth and Atmospheric Sciences, Department

2001

\title{
Vertical Profiles of Streambed Hydraulic Conductivity Determined Using Slug Tests in Central and Western Nebraska
}

\author{
David L. Rus \\ United States Geological Survey, Lincoln, Nebraska \\ Virginia L. McGuire \\ United States Geological Survey, Lincoln, Nebraska \\ Brian R. Zurbuchen \\ United States Environmental Protection Agency, zurbuchen.brian@epa.gov \\ Vitaly A. Zlotnik \\ University of Nebraska-Lincoln, vzlotnik1@unl.edu
}

Follow this and additional works at: https://digitalcommons.unl.edu/geosciencefacpub

Part of the Earth Sciences Commons

Rus, David L.; McGuire, Virginia L.; Zurbuchen, Brian R.; and Zlotnik, Vitaly A., "Vertical Profiles of Streambed Hydraulic Conductivity Determined Using Slug Tests in Central and Western Nebraska" (2001). Papers in the Earth and Atmospheric Sciences. 189.

https://digitalcommons.unl.edu/geosciencefacpub/189

This Article is brought to you for free and open access by the Earth and Atmospheric Sciences, Department of at DigitalCommons@University of Nebraska - Lincoln. It has been accepted for inclusion in Papers in the Earth and Atmospheric Sciences by an authorized administrator of DigitalCommons@University of Nebraska - Lincoln. 


\section{Vertical Profiles of Streambed Hydraulic Conductivity Determined Using Slug Tests in Central and Western Nebraska}

By David L. Rus, Virginia L. McGuire, Brian R. Zurbuchen, and Vitaly A. Zlotnik

U.S. GEOLOGICAL SURVEY

Water-Resources Investigations Report 01-4212

Prepared in cooperation with the NEBRASKA PLATTE RIVER COOPERATIVE HYDROLOGY STUDY GROUP 


\section{U.S. DEPARTMENT OF THE INTERIOR GALE A. NORTON, Secretary}

U.S. GEOLOGICAL SURVEY

Charles G. Groat, Director

The use of firm, trade, and brand names in this report is for identification purposes only and does not constitute endorsement by the U.S. Geological Survey.

For additional information write to:

District Chief

U.S. Geological Survey, WRD

406 Federal Building

100 Centennial Mall North

Lincoln, NE 68508

http://www.usgs.gov
Copies of this report can be purchased from:
U.S. Geological Survey
Information Services
Box 25286
Federal Center
Denver, CO 80225 


\section{CONTENTS}

Abstract

Introduction

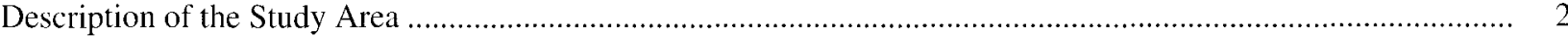

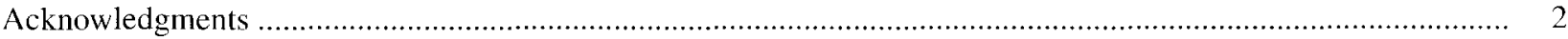

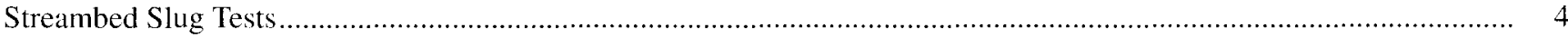

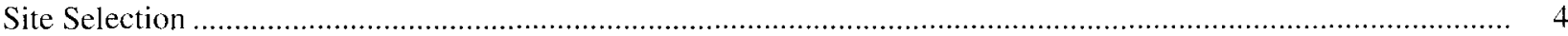

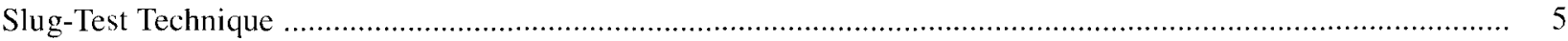

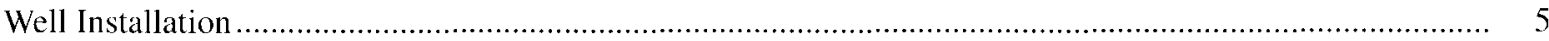

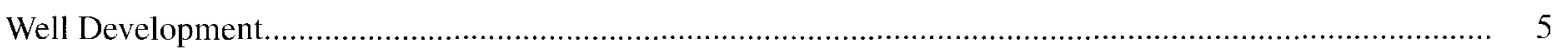

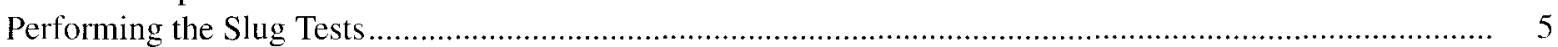

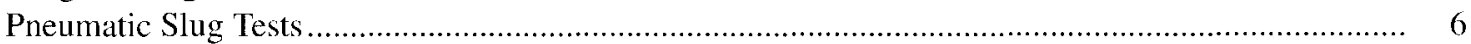

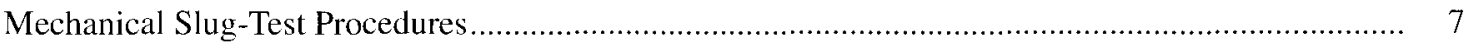

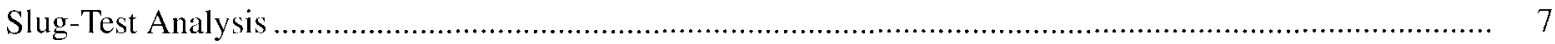

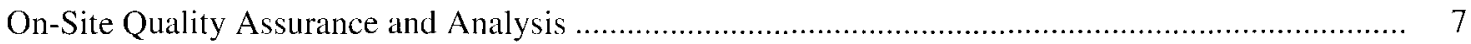

Bouwer and Rice Method ............................................................................................. 7

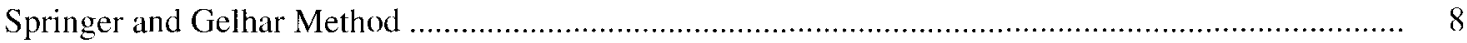

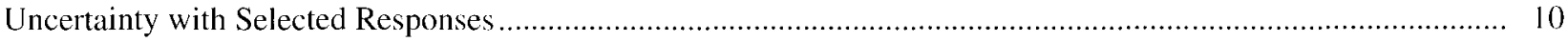

Comparison of Horizontal Hydraulic Conductivity Data with Nearby Lithologic Descriptions .......................... 11

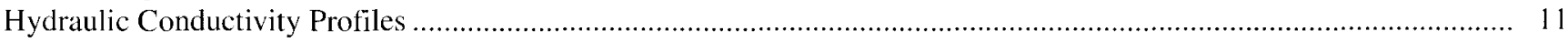

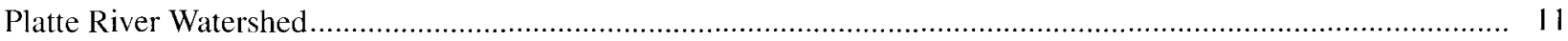

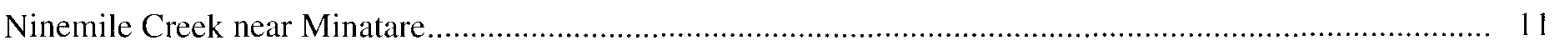

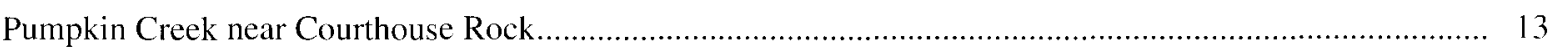

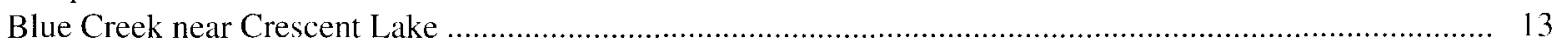

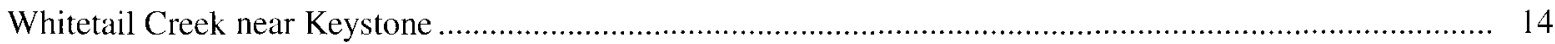

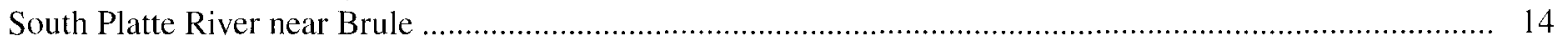

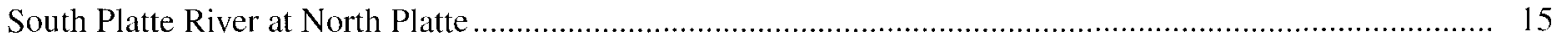

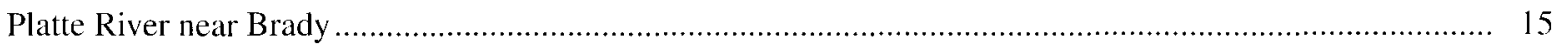

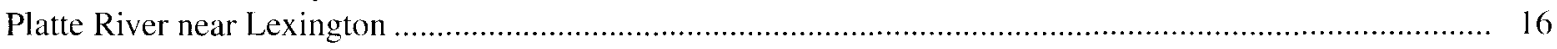

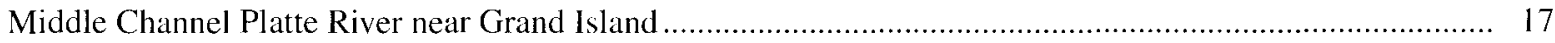

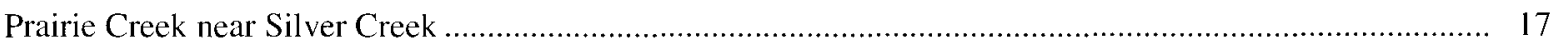

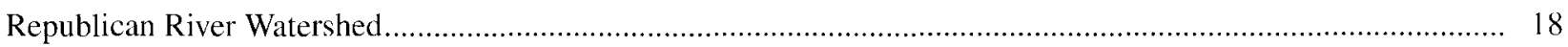

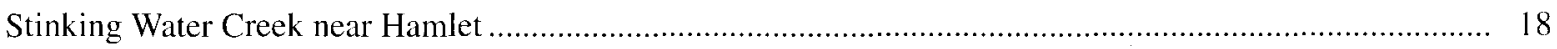

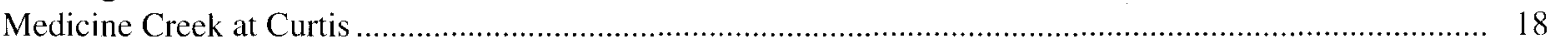

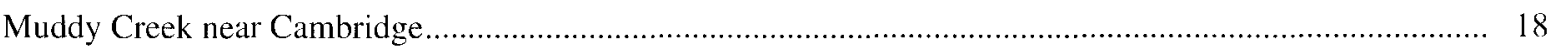

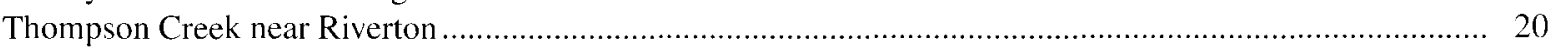

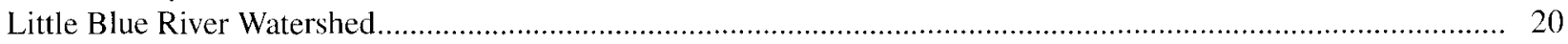

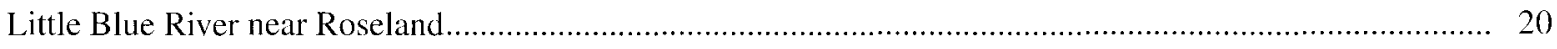

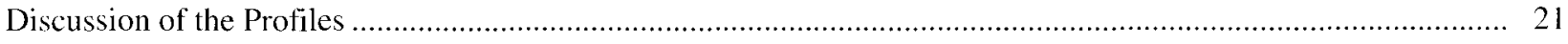

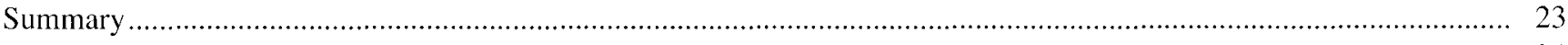

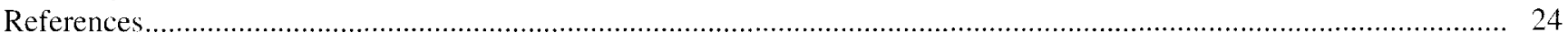

Appendix. Individual measurements of streambed hydraulic conductivity ......................................................29

\section{FIGURES}

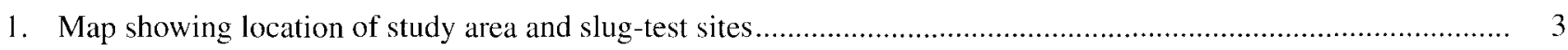

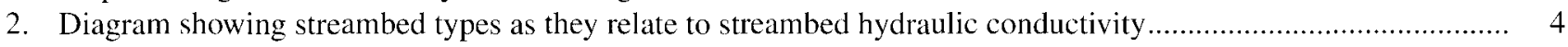

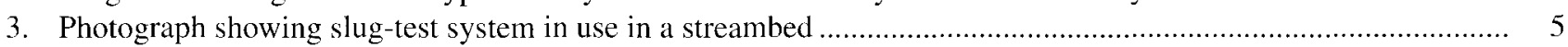

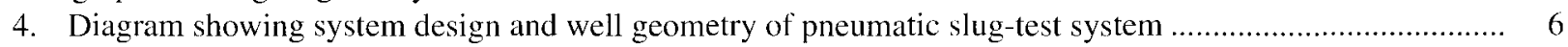


5-19. Graphs showing:

5. Bouwer and Rice method for measuring hydraulic conductivity showing (A) a plot of response data and $(\mathrm{B})$ the basic equations and the anisotropy correction developed by Zlotnik

6. Springer and Gelhar method for measuring hydraulic conductivity showing (A) a plot of response data with various type curves and (B) the solution equations .....

7. Profile of hydraulic conductivity, Ninemile Creek near Minatare ............................................................ 13

8. Profile of (A) hydraulic conductivity and (B) basic lithology from a nearby bridge borehole, Pumpkin Creek near Courthouse Rock.

9. (A) Hydraulic conductivity profile and (B) photograph of the Blue Creek study site near Crescent Lake...... 14

10. Profile of hydraulic conductivity, Whitetail Creek near Keystone ......................................................... 14

11. Profile of (A) hydraulic conductivity and (B) basic lithology from a nearby bridge borehole, South Platte River near Brule.

12. Profile of (A) hydraulic conductivity and (B) basic lithology from a nearby bridge borehole, South Platte River at North Platte.

13. Profile of (A) hydraulic conductivity and (B) basic lithology from a nearby bridge borehole, Platte River near Brady

14. Profile of (A) hydraulic conductivity and (B) basic lithology from a nearby bridge borehole, Platte River near Lexington

15. Profile of (A) hydraulic conductivity and (B) basic lithology from a nearby bridge borehole, Middle Channel Platte River near Grand Island

16. Profile of (A) hydraulic conductivity and (B) basic lithology from a nearby bridge borehole, Prairie Creek near Silver Creek

17. Profile of (A) hydraulic conductivity and (B) basic lithology from a nearby test hole, Stinking Water Creek near Hamlet

18. Profile of (A) hydraulic conductivity and (B) basic lithology from a nearby bridge borehole, Medicine Creek at Curtis

19. Profile of (A) hydraulic conductivity and (B) basic lithology from a nearby bridge borehole,

Muddy Creek near Cambridge.

20. Photograph of outcrop of probable Ogallala Formation near the Muddy Creek near Cambridge site

21-22. Graphs showing:

21. Profile of (A) hydraulic conductivity and (B) basic lithology from a nearby test hole,

Thompson Creek near Riverton

22. Profile of (A) hydraulic conductivity and (B) basic lithology from a nearby bridge borehole, Little Blue River near Roseland

23. Boxplots of isotropic horizontal hydraulic conductivity for each site using (A) streambed measurements only and (B) all measurements

\section{TABLES}

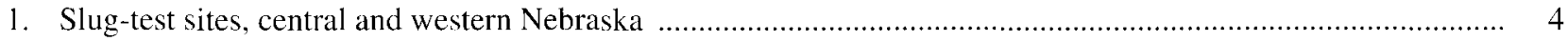

2. Summary statistics of horizontal hydraulic conductivity by site .................................................................. 12

\section{CONVERSION FACTORS}

\begin{tabular}{rll}
\hline Multiply & By & To obtain \\
\hline inch (in.) & 2.54 & centimeter \\
inch (in.) & 25.4 & millimeter \\
foot (ft) & 0.3048 & meter \\
mile (mi) & 1.609 & kilometer \\
foot per day (ft/d) & 0.3048 & meter per day \\
foot per day (ft/d) & 0.0003528 & centimeter per second \\
pounds per square inch (psi) & 51.71 & millimeters of mercury \\
\hline
\end{tabular}




\title{
Vertical Profiles of Streambed Hydraulic Conductivity Determined Using Slug Tests in Central and Western Nebraska
}

\author{
By David L. Rus, ${ }^{1}$ Virginia L. McGuire, ${ }^{1}$ Brian R. Zurbuchen, ${ }^{2}$ and Vitaly A. Zlotnik ${ }^{2}$
}

\section{Abstract}

Many issues of water-resources management rely on modeling of ground-water/surfacewater interactions, and streambed hydraulic conductivity is a key parameter controlling the water fluxes across the stream/aquifer interface. However, in central and western Nebraska, this parameter is generally undefined. The U.S. Geological Survey, in cooperation with the Nebraska Platte River Cooperative Hydrology Study Group, performed slug tests at 15 stream sites in the Platte, Republican, and Little Blue River watersheds to determine the hydraulic conductivity of streambeds in central and western Nebraska. Slug tests were completed at several discrete depth intervals using pneumatic or mechanical methods, and the water-level response was monitored on site using a pressure transducer and laptop computer. Responses were analyzed using either the Bouwer and Rice or Springer and Gelhar methods. Vertical profiles of hydraulic conductivity with depth were developed and were compared to available information on lithology.

The profiles and corresponding lithology showed that different types of streambeds were tested and suggested that some streambeds display a large variability in hydraulic conductivity with depth. In some cases, hydraulic conductivity values associated with nonstreambed

\footnotetext{
${ }^{1}$ U.S. Geological Survey, Lincoln, Nebraska.

${ }^{2}$ University of Nebraska-Lincoln, Department of Geosciences, Lincoln, Nebraska.
}

materials could be identified from nearby lithologic descriptions. Seven of 15 sites had streambed values that ranged over more than 3 orders of magnitude, and that variability increased significantly when the measurements considered to be from nonstreambed materials were included. Streambed profiles from the Platte and South Platte River sites generally were more homogeneous and of larger hydraulic conductivity than the other sites. No restrictive layers were detected at any of the streambed sites on the main stems or the flood plains of the main stems of their respective watersheds. Alternatively, the profiles characterized by a restrictive streambed layer at some depth below the streambed surface were all from tributary sites out of the main-stem flood plain. These profiles can be used to represent the streambed hydraulic conductivity in central and western Nebraska in various applications, including modeling ground-water/surfacewater interactions.

\section{INTRODUCTION}

Understanding ground-water/surface-water (GW/SW) interactions is often an important issue in water-resources management. Because the streambed hydraulic conductivity $(\mathrm{K})$ is a key parameter controlling the water fluxes across the stream/aquifer interface, estimating its value is an important step in characterizing these interactions. This is especially true when the streambed has a lower $\mathrm{K}$ than the aquifer, thereby restricting GW/SW fluxes (Rosenshein, 1988; Larkin and Sharp, 1992; Conrad 
and Beljin, 1996). Determination of streambed K can be important for studies designed to determine base flow (Petersen and others, 1995; Cey and others, 1998), to quantify the effects of pumping wells on streamflow (Sophocleous and others, 1995; Chen and Yin, 1999; Hunt, 1999), to simulate regional groundwater-flow balances (McDonald and Harbaugh, 1988; Luckey and Becker, 1999; Yu and Schwartz, 1999), to study bank storage effects (Zlotnik and Huang, 1999), and to quantify solute transport, retention, and exchange between ground water and surface water (Harvey and Bencala, 1993; McMahon and others, 1995; Hart and others, 1999). The Nebraska Platte River Cooperative Hydrology Study Group (COHYST), as part of its effort to simulate groundwater flow balances in central and western Nebraska, needs to understand the role of streambed conductance in the ground-water-flow system and its interrelation with surface-water flow (Cooperative Hydrology Study Group, accessed May 30, 2001). In this report, the term "streambed" is applied to the saturated alluvium immediately beneath the stream.

A study completed by Landon and others (in press) determined that field permeameter, grain-size analysis, and slug-test methods all produced relatively similar measurements of streambed $\mathrm{K}$ when the spatial variability among sites was considered. These researchers also suggested that the materials restricting GW/SW fluxes often were several feet below the surface of the streambed, and that the relevance of the measurement technique was dependent on the expected vertical location of the restrictive (less conductive) layer.

In cases where the streambed surface limited GW/SW interaction, field permeameter methods were appropriate to define the $\mathrm{K}$ value of the restrictive layer. However, where the restrictive layer was presumed to be beneath the streambed surface, field permeameter methods were unsuitable, and grain-size analysis methods, aquifer-pump tests, and slug tests were considered in those cases. Grain-size methods, which relate the grain-size distribution of sediment cores to $\mathrm{K}$ using empirical formulas, were ruled out because they did not account for the influence of sediment structure and packing on K (Taylor and others, 1990; Zlotnik and others, 2000) and were prone to retrieval problems. Aquifer pumping tests also were ruled out because they were cost prohibitive and would produce values at a larger measurement scale than the field permeameters. Consequently, slug-test methods, which measure horizontal hydraulic conductivity $\left(\mathrm{K}_{\mathrm{h}}\right)$ as a function of the response of the water level in a well to a displacement, were selected to produce streambed $K_{h}$ values on a localized scale following the method of Hinsby and others (1992). Although vertical hydraulic conductivity $\left(\mathrm{K}_{\mathrm{v}}\right)$ is needed to define streambed conductance, slug-test methods give measures of $K_{h}$. The difference between $K_{v}$ and $K_{h}$ represents the anisotropy of the sediments and usually does not vary more than 1 order of magnitude $\left(\mathrm{K}_{\mathrm{h}} / \mathrm{K}_{\mathrm{v}}\right.$ equals 10) for large-scale pumping tests in alluvium (Freeze and Cherry, 1979).

Based on these conclusions, a cooperative study was initiated by the U.S. Geological Survey and the COHYST Group to characterize profiles of streambed $\mathrm{K}$ relative to depth at selected sites in the COHYST study area (fig. 1) using slug-test methods capable of producing measurements of $\mathrm{K}$ over a wide range of values. The profiles then were compared to descriptions of nearby lithology, when available, to isolate measurements of streambed $\mathrm{K}$ from measurements associated with aquifer or other materials. This report presents the results of the study.

\section{Description of the Study Area}

Although the COHYST study area is focused on the surface-water drainage system of the Platte River in Nebraska upstream from Columbus, Nebraska, it also includes parts of the Loup, Republican, Big Blue, and Little Blue River drainage systems (fig. 1).

Streams in the study area are hydraulically connected to ground water in alluvial deposits of Quaternary age and the Ogallala and Brule Formations of Tertiary age. The Platte River channels predominantly are braided, and the bed material consists primarily of sand and gravel. The other streams in the study area generally have well-defined meandering channels with streambeds varying in texture from gravel to clay-sized particles.

\section{Acknowledgments}

The authors thank the COHYST Group for extensive logistical and planning support. The authors also thank Clint P. Carney, Christopher M. McCormick, Steven M. Peterson, and Richard A. Kern, COHYST Group, for valuable assistance in the collection of slug-test data; Gregory V. Steele and 


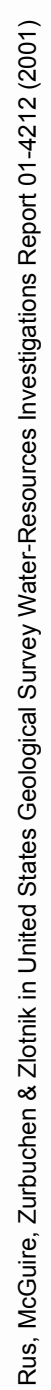
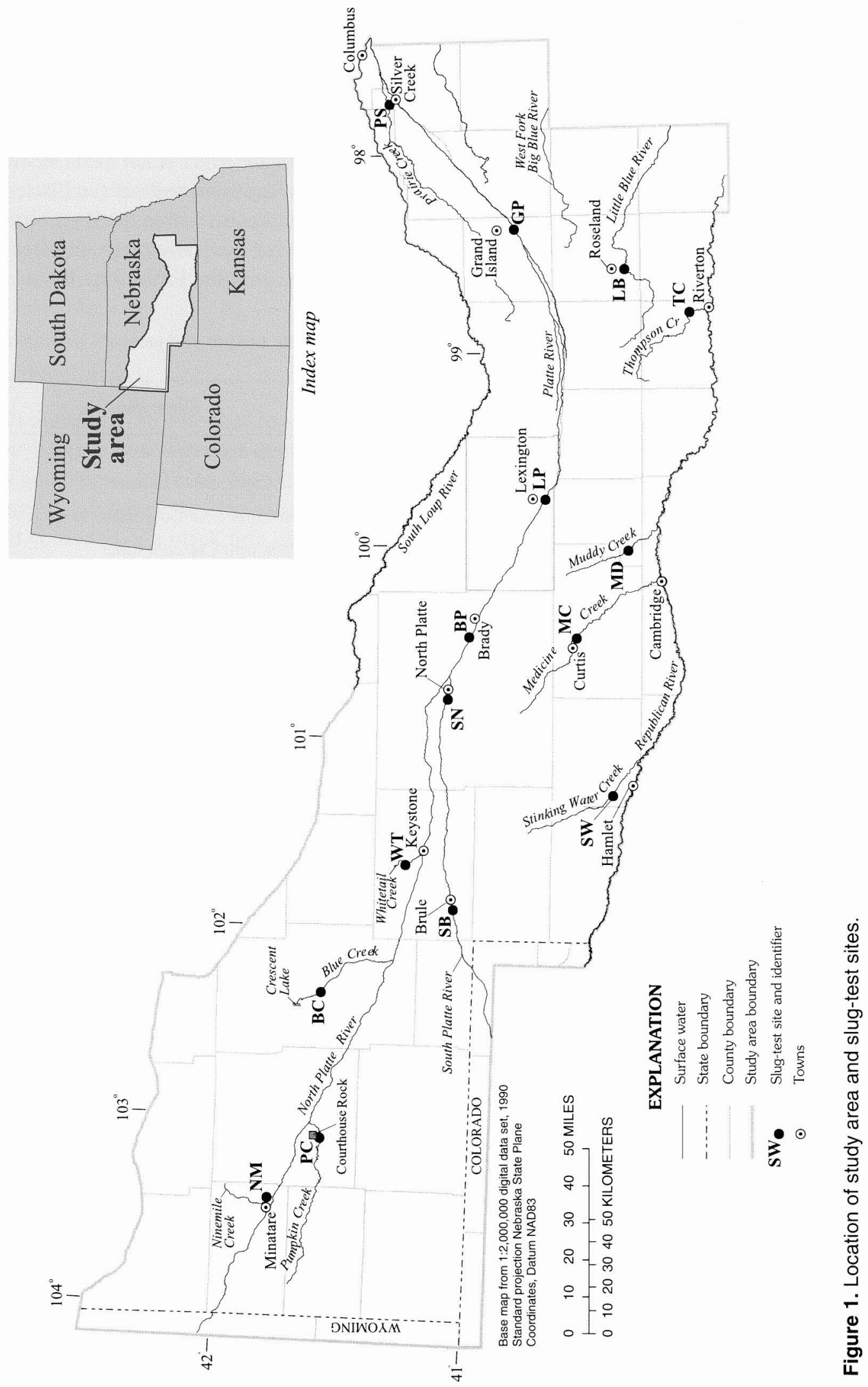
Alan W. Burns, U.S. Geological Survey, for their review of the slug-test results; and Scott C. Christenson and Edwin P. Weeks for their helpful comments after reviewing this manuscript.

\section{STREAMBED SLUG TESTS}

Slug-test techniques in temporary wells were used to measure streambed $\mathrm{K}_{\mathrm{h}}$. After the well was installed and developed, the water level was displaced using either pneumatic methods or mechanical slugtest methods, depending on the recovery of the water level. The recorded responses then were analyzed using Bouwer and Rice (1976) or Springer and Gelhar (1991) methods. Once data collection was complete and results were assembled into profiles with depth, lithologic descriptions were compiled from available sources for comparison to the profiles of $\mathrm{K}_{\mathrm{h}}$.

\section{Site Selection}

Based on the conclusions of Landon and others (in press), three types of streambeds were identified in the study area (fig. 2): (A) those where materials at the surface of the streambed restrict interaction with the aquifer below; (B) those where restrictive materials are below the streambed surface; and (C) those with no restrictive materials limiting GW/SW interaction.

Because $\mathrm{K}$ could be defined adequately in streambed types $\mathrm{A}$ and $\mathrm{C}$ using field permeameters, slug-test techniques were necessary only in type B streambeds, although they could also be used to verify streambed type for all three scenarios.

Prior to this study, 55 sites in the study area were evaluated using cores collected from the upper $4 \mathrm{ft}$ (feet) of the streambed to estimate the streambed type (Steven M. Peterson, Cooperative Hydrology Study Group, written commun., 2000). At sites assessed as types $\mathrm{A}$ or $\mathrm{C}$, permeameter measurements were made to obtain $\mathrm{K}$ values. A subset of 15 sites assumed to be type B or type $\mathrm{C}$ then was selected for the characterization of $\mathrm{K}$ profiles using slug-test techniques for this study (fig. 1, table 1). Of the 15 sites, 10 were within the Platte River watershed (of which five were directly on the main stem of the Platte or South Platte Rivers), 4 were within the Republican River watershed (all tributary streams to the Republican River), and 1 was on the Little Blue River.

Table 1. Slug-test sites, central and western Nebraska

\begin{tabular}{cl}
\hline $\begin{array}{c}\text { Site code } \\
\text { (fig. 1) }\end{array}$ & \multicolumn{1}{c}{ Site name } \\
\hline NM & \multicolumn{1}{c}{ Ninemilte River Watershed } \\
PC & Pumpkin Creek near Courthouse Rock \\
BC & Blue Creek near Crescent Lake \\
WT & Whitetail Creek near Keystone \\
SB & South Platte River near Brule \\
SN & South Platte River at North Platte \\
BP & Platte River near Brady \\
LP & Platte River near Lexington \\
GP & Middle Channel Platte River near Grand Island \\
PS & Prairie Creek near Silver Creek \\
& Republican River Watershed \\
SW & Stinking Water Creek near Hamlet \\
MC & Medicine Creek at Curtis \\
MD & Muddy Creek near Cambridge \\
TC & Thompson Creek near Riverton \\
& Little Blue River Watershed \\
LB & Little Blue River near Roseland \\
\hline
\end{tabular}
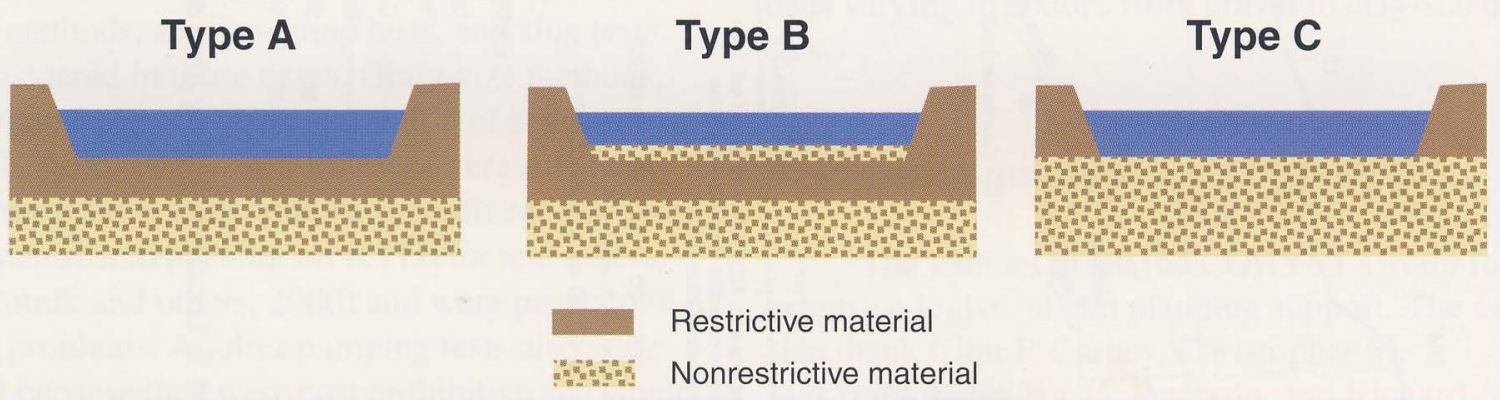

Figure 2. Streambed types as they relate to streambed hydraulic conductivity. 


\section{Slug-Test Technique}

A slug-test technique was designed for this study to test discrete vertical regions of streambed material with widely varying values of $\mathrm{K}$. The technique was designed to minimize well skins (collections of fine material around the well screen) and frictional losses in hydraulic head in the wells during the tests, which complicate the analysis (Zurbuchen and others, in press), and to detect their presence when they affected the test response. These effects had the potential to complicate or even prohibit the analysis of the test response.

\section{Well Installation}

To minimize the disturbance to the surrounding materials being tested, direct-push methods were used (Hinsby and others, 1992) to drive a temporary well to the desired depth below the streambed surface (fig. 3). The well consisted of a black iron casing with a stainless steel screen and drive point. The diameter of the well needed to be large enough to prevent significant

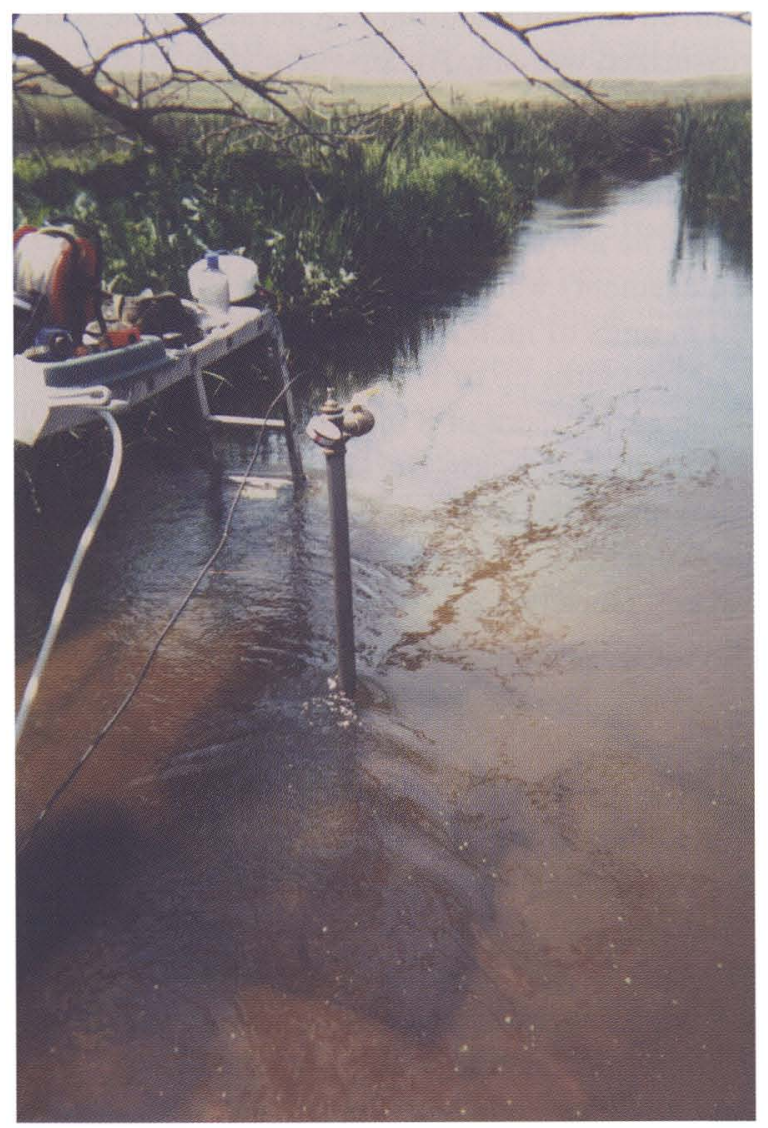

Figure 3. Slug-test system in use in a streambed. friction losses, but small enough to drive to the target depth. The final inside casing radius of $0.64 \mathrm{in}$. (inches) (outside radius was 0.83 in.) was selected by modeling the predicted response for a given diameter with the highest $\mathrm{K}$ value expected. The inside radius of the screen ( $0.69 \mathrm{in}$.) was only slightly larger than the casing, and no head losses were assumed as water moved from the casing to the screen or screen to casing. The screen had an open area of 10 percent with individual slot openings 0.007 in. wide. This was considered sufficient to allow for unrestricted flow into or out of the well. An 8-in.-long well screen (fig. 4) was used to allow for differentiation between depths. Based on the profile created from the slug-test results of the PS site, a 2-ft interval between test depths was assumed to be adequate to represent the streambed materials. The process of driving to the desired test depth, developing the well, and then performing the tests was repeated until a target depth of $20 \mathrm{ft}$ was achieved or impenetrable materials were encountered (refusal).

\section{Well Development}

After the well screen was set to the desired depth, the well was developed to remove any low-K well skins that may have formed around the screen. The well was surged with as many as 30 vigorous strokes of sealed polyvinyl chloride pipe and then pumped out until the water became clear, indicating that the well had been purged sufficiently. If the water remained fairly sediment laden, the process of surging and pumping was repeated one or two more times.

In some instances after surging, the water did not recover and the well was pumped dry. Water then was added, the well was surged again, and the water pumped out. If, after the third series of surging and pumping, the well could still be pumped dry, this was assumed to be a result of poorly conductive materials rather than a plugged screen, and development was considered complete.

\section{Performing the Slug Tests}

After completion of well development, waterlevel measurements were made to define the screen depth with respect to static (equilibrium) water level. When the water level recovered quickly following development (for example, within 20 minutes), the static water level was determined using an electric 


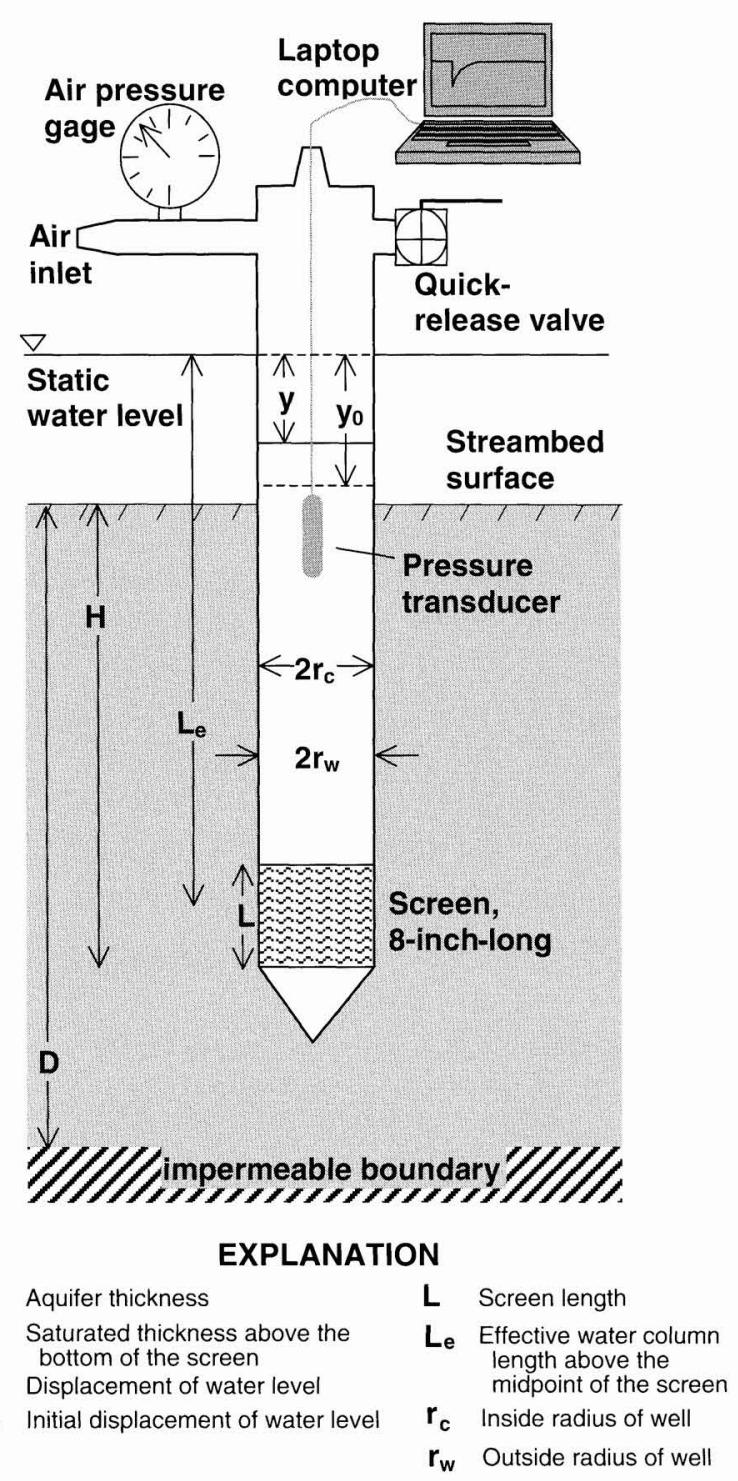

Figure 4. System design and well geometry of pneumatic slug-test system.

measuring tape. However, if the water level recovered slowly, two options were available for assuming the static level in the well with respect to the surrounding surface-water level. If a difference between the ground-water and surface-water levels was measured at an adjacent depth, the same difference was assumed for the slug-test depth, and the static level in the well was computed accordingly. Otherwise, the static water level simply was assumed to be the same as the surface-water level. Although it was desirable to allow full water-level recovery in the well to measure the static water level, time limitations occasionally prevented this.
The rate of water-level recovery determined the type of slug test performed. When the water level recovered quickly, pneumatic slug tests were performed. These tests involved changing the air pressure inside the well casing to displace the water level. When the water level recovered slowly, mechanically initiated slug tests were performed, which involved adding or removing water from the well to set the initial water-level displacement.

In most cases, slug-test response data were measured using a Druck ${ }^{\mathrm{TM}}$ PDCR 35/D 10-psi submersible pressure transducer. Based on the work of Zurbuchen and others (in press), the transducer was placed just below the maximum-targeted initial displacement in the well to avoid anomalous pressure readings at the onset of the test. The transducer was attached to a Campbell ${ }^{\mathrm{TM}} \mathrm{CR} 10 \mathrm{X}$ data logger, which in turn was connected to a laptop computer (fig. 4). This system allowed for real-time plots of the slug-test responses and nearly real-time analyses of the data.

\section{Pneumatic Slug Tests}

For the pneumatic tests, the top of the well was sealed with an airtight manifold that permitted the well to be pressurized with air. An air-valve stem attachment (similar to that found on a bicycle wheel) was used to inject air into the well casing using a bicycle pump. The air pressurization displaced the water level in the well. The air pressure (and subsequent waterlevel displacement) was monitored using a gage that measured in units of inches of water (capable of reading air pressures up to 15 in. of water). For example, an air pressure of 8 in. of water equated to a displacement of 8 in. below the static water level. The air pressure inside the well was adjusted until the gage read a pressure identical to the targeted initial displacement. Once this was done, the data logger was set to begin recording, and a quick-release valve on the manifold (fig. 4) was opened to depressurize the system and begin the test.

Friction losses are introduced by the movement of the water column along the inside wall of the well during a slug-test response and can be an important factor in testing highly conductive aquifers. Although it is impossible to eliminate the effects of friction, using small initial water-level displacements can minimize such losses and their presence can be detected by performing multiple tests with different initial displacements (Zurbuchen and others, in press). 
Therefore, tests were performed using three different initial displacements $(4,8$, and 12 in.) at each depth.

\section{Mechanical Slug-Test Procedures}

The pneumatic approach is not well suited to media of low hydraulic conductivity because of the long time required for the pressurized water level to attain quasi-equilibrium before the system can be depressurized to begin the test (Butler, 1998). In cases where the water level in the well recovered slowly following well development, it was assumed that low conductivity materials were being tested, and the slug tests were performed by rapidly adding water (fallinghead tests) or removing water (rising-head tests) to induce an initial displacement.

Most nonpneumatic slug tests were rising-head tests. Water was pumped mechanically from the well to displace the water level below static, the transducer was placed at the bottom of the well, and water-level recording began. Because the water level rose slowly, the initial displacement was estimated by the transducer as the lowest recorded reading. The response was recorded for 20 minutes or until the water level had fully recovered, whichever came first.

At sites SB, SN, and BP, falling-head tests were performed when the conductivity was too low for pneumatic methods. Water was added to the well to raise the water above static level, and the falling water level was determined by measuring the distance down from the top of the well to the water periodically to determine the water-level change. Although these measurements were not as frequent or accurate as those provided by the pressure transducer, they were sufficient to develop response curves from which $\mathrm{K}$ measurements could be derived.

\section{Slug-Test Analysis}

To ensure that $\mathrm{K}$ could be measured successfully, on-site quality-assurances and analyses were performed on responses using a computer program specifically designed for this study. Satisfactory response data then were interpreted using one of two related analytical solutions. When the water level took longer than 30 seconds to recover, responses were analyzed using the method of Bouwer and Rice (1976). For all other tests, responses were analyzed using the technique of Springer and Gelhar (1991), who modified the Bouwer and Rice method to incorporate inertial effects of the water column in the well.

\section{On-Site Quality Assurance and Analysis}

The analysis of slug-test responses can be complicated or even precluded by the introduction of nonlinear effects, especially when the tests are performed in highly conductive materials (Butler, 1998; Zurbuchen and others, in press). Although the well was designed to minimize these effects, it would be impossible to remove them entirely, and it is often too late to account for these effects if they are discovered after completion of the data collection. For these reasons, a system was created that allowed the responses to be monitored and analyzed on site.

For each slug test, a laptop computer recorded the response data measured with the pressure transducer (fig. 4). This computer was used to show the response in real time and to analyze the response immediately afterwards. By monitoring the response, nonlinear effects and procedural errors could be identified and addressed. For example, if opening the quickrelease valve on the well did not create an instantaneous initial displacement, the resulting effect on the response curve could be observed, and the test could be run again.

After the responses were recorded, they could be analyzed further to ensure that nonlinear effects were not dominant and that $K$ values could be measured before driving the well screen to the next lower depth. Following the recommendations of Zurbuchen and others (in press), a computer program written for this study automatically plotted normalized response data for each displacement on the same graph. If the responses were significantly different, the well was developed further and an additional set of tests was performed. The computer program also measured $\mathrm{K}$ from the initial 30 seconds of the response data using the Springer and Gelhar (1991) method (as described in the next sections) to verify the match of the response to theoretical type curves. For timesaving purposes, only oscillatory responses were interpreted in the field before the well was driven to the next depth. Otherwise, the responses were analyzed later.

\section{Bouwer and Rice Method}

The method of Bouwer and Rice (1976) was used to measure $\mathrm{K}_{\mathrm{h}}$ for the pneumatic slug-test responses lasting more than 30 seconds and all mechanical slug-test responses. This method assumes steady-state flow into or out of a well when the water 
level is displaced from the static level of the surrounding aquifer. This method consists of three components. First, the response data are normalized and plotted on a semilogarithmic graph (fig. 5A) and the slope of the linear part of the response is determined. Next, a value of $\ln \left(R_{e} / r_{w}{ }^{*}\right)$ is computed using the equation for partially penetrating wells (fig. 5B, eq. 1) with the empirical coefficients $A$ and $B$ found as a function of the screen length, $L$, and the outside radius of the well, $r_{w}$. A measurement of $K_{h}$ then is calculated from these variables (fig. 5B, eq. 2).

The Bouwer and Rice method assumes isotropic conditions (where $\mathrm{K}_{\mathrm{h}}$ is equal to the $\mathrm{K}_{\mathrm{v}}$ of the materials being tested), and Zlotnik (1994) extended this method for anisotropic sediments. Using Zlotnik's method, the outside well radius, $r_{w}$ is modified by accounting for an anisotropy ratio $\left(\mathrm{K}_{\mathrm{h}} / \mathrm{K}_{\mathrm{v}}\right)$ (fig. $5 \mathrm{~B}$, eq. 3 ) to produce the corrected outside well radius $r_{w}{ }^{*}$. Subsequently, $r_{w}{ }^{*}$ is substituted for $r_{w}$ in equation 1 (fig. 5B). The presence of anisotropy was anticipated, but the magnitude of the anisotropy was unknown, so $\mathrm{K}_{\mathrm{h}}$ measurements were computed considering isotropic conditions ( $\mathrm{K}_{\mathrm{h}} / \mathrm{K}_{\mathrm{V}}$ equals 1 ) and for the

A

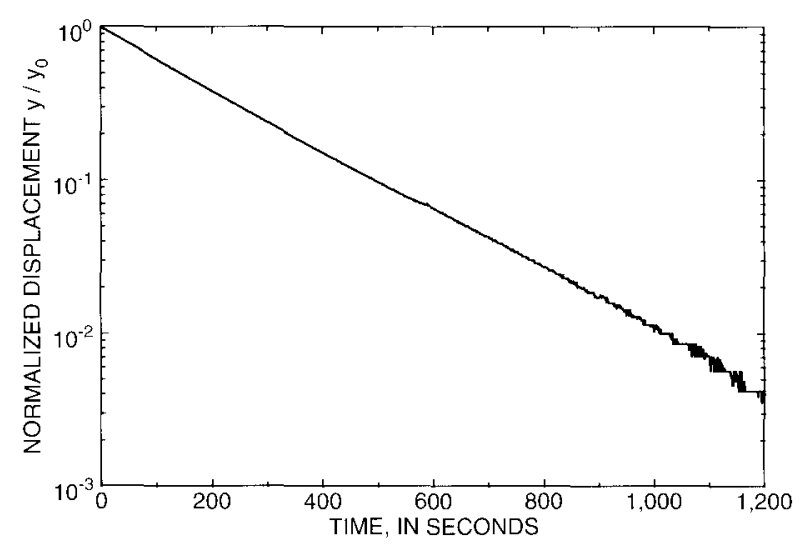

anisotropy ratio typically determined from large-scale pumping tests in alluvium $\left(\mathrm{K}_{\mathrm{h}} / \mathrm{K}_{\mathrm{v}}\right.$ equals 10 ) (Freeze and Cherry, 1979).

\section{Springer and Gelhar Method}

The Springer and Gelhar (1991) method was used to solve responses that recovered within 30 seconds. This method accounts for inertial effects of the moving water column in the well. In cases where the water level recovers rapidly, the momentum of the water column can be sufficient to induce oscillations in the response (fig. 6A). These oscillations follow the behavior of a damped spring and occur when the slug tests are conducted in wells that are screened in zones of high hydraulic conductivity or in wells with long columns of water above the screen (van der Kamp, 1976). Zlotnik and McGuire (1998) demonstrated that this method reduces to the Bouwer and Rice method for low-K material.

The Springer and Gelhar method measures $\mathrm{K}_{\mathrm{h}}$ by matching a type curve to the response curve. The type curves are dependent on the Springer and Gelhar well factor, $F_{0}$ (fig. 6 ), which describes the degree of

\section{B Basic equations}

$$
\begin{aligned}
& \ln \left[\frac{\mathrm{R}_{e}}{\mathrm{r}_{\mathrm{w}}^{*}}\right]=\left[\frac{1.1}{\ln \left[\frac{\mathrm{H}}{r_{\mathrm{w}}^{*}}\right]}+\frac{\mathrm{A}+\mathrm{B} \ln \left[\frac{(\mathrm{D}-\mathrm{H})}{\mathrm{r}_{\mathrm{w}}^{*}}\right]}{\frac{\mathrm{L}}{\mathrm{r}_{\mathrm{w}}^{*}}}\right]^{-1} \\
& \mathrm{~K}_{\mathrm{h}}=\frac{\mathrm{r}_{\mathrm{c}}^{2} \ln \left[\frac{\mathrm{R}_{\mathrm{e}}}{\mathrm{r}_{\mathrm{w}}^{*}}\right]_{1}}{2 \mathrm{~L}} \ln \left[\frac{\mathrm{y}_{0}}{\mathrm{y}}\right] \\
& \mathrm{r}_{\mathrm{w}}^{*}=\frac{\mathrm{r}_{\mathrm{w}}}{\sqrt{\frac{\mathrm{K}_{\mathrm{h}}}{\mathrm{K}_{\mathrm{v}}}}}
\end{aligned}
$$

\section{EXPLANATION}

$\begin{array}{ll}y & \text { Displacement of water level } \\ R_{e} & \text { Effective aquifer radius } \\ A, B & \text { Bouwer and Rice (1976) empirical coefficients } \\ H & \text { Saturated thickness above screen } \\ r_{c} & \text { Inside radius of well } \\ K_{h} & \text { Horizontal hydraulic conductivity } \\ K_{v} & \text { Vertical hydraulic conductivity }\end{array}$

$y_{0} \quad$ Initial displacement of water level

$r_{W}$ Outside radius of well

D Aquifer thickness

$L$ Screen length

$t$ Time

$r_{w}^{*}$ Outside radius of well corrected

Figure 5. Bouwer and Rice (1976) method for measuring hydraulic conductivity showing (A) a plot of response data and (B) the basic equations (eqs. 1 and 2 ) and the anisotropy correction (eq. 3 ) developed by Zlotnik (1994). 


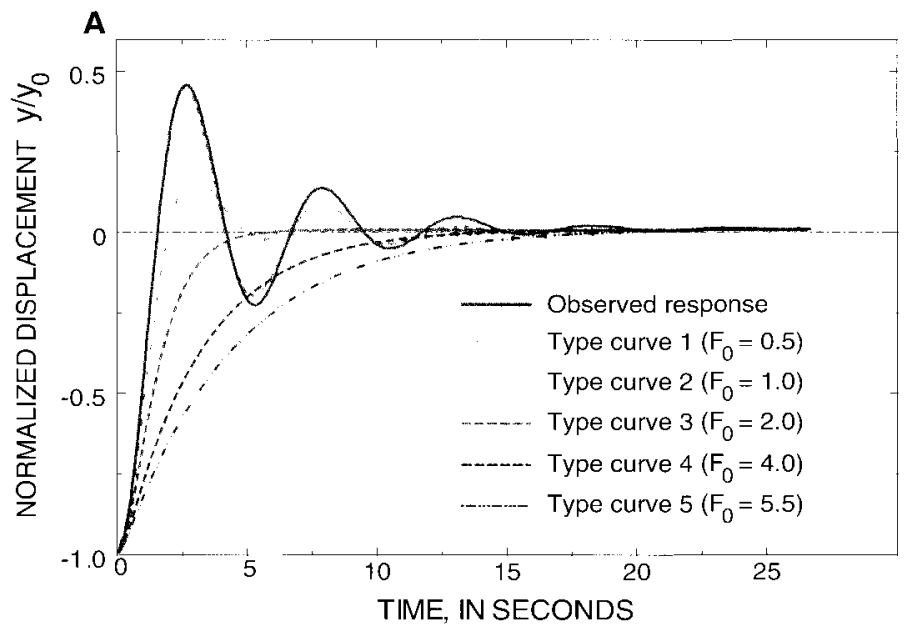

B

Solution equations

Overdamped $(F \circ>2.0)$ type curve equation: $w(\tau)=\frac{-1}{\gamma_{-}-\gamma_{+}}\left(\gamma_{-} e^{\gamma_{+} \tau}-\gamma_{+} e^{\gamma_{-} \tau}\right)$

Where:

$\gamma_{+}=\frac{-F_{0}}{2}+\sqrt{\frac{F_{0}^{2}}{4}-1} ;$ and $\gamma_{-}=\frac{-F_{0}}{2}-\sqrt{\frac{F_{0}^{2}}{4}-1}$

Critically damped $\left(F_{0}=2.0\right)$ type curve equation: $\quad w(\tau)=-e^{(-\tau)}[1+\tau]$

Underdamped $\left(F_{0}<2.0\right)$ type curve equation: $\quad w(\tau)=-e^{\left(-F_{0} \frac{\tau}{2}\right)}\left[\cos (\gamma \tau)+\frac{F_{0}}{2 \gamma} \sin (\gamma \tau)\right]$

Where: $\gamma=\sqrt{1-\frac{F_{0}^{2}}{4}}$

$$
K_{h}=\sqrt{\frac{g}{L_{e}}} \times \frac{r_{c}^{2} \ln \left[\frac{R_{e}}{r_{w}^{*}}\right]}{2 F_{0} L}
$$

\section{EXPLANATION}

$\begin{array}{cl}y & \text { Displacement of water level } \\ W(\tau) & \begin{array}{l}\text { Type curve function representing the } \\ \text { dimensionless displacement, } y / y_{0}\end{array} \\ F_{0} & \text { Springer and Gelhar (1991) well factor } \\ g & \text { Gravitational constant } \\ r_{C} & \text { Inside radius of well } \\ L & \text { Screen length }\end{array}$

$\mathrm{y}_{0} \quad$ Initial displacement of water level

$\tau \quad$ Dimensionless time $=\mathrm{t} \sqrt{\frac{\mathrm{g}}{\mathrm{L}_{e}}} ;$ where $\mathrm{t}$ is time

$\mathrm{K}_{\mathrm{h}} \quad$ Horizontal hydraulic conductivity

$\mathrm{L}_{\mathrm{e}} \quad$ Effective water column length

$\ln \left[\frac{R_{e}}{r_{w}^{*}}\right] \begin{gathered}\text { Bouwer and Rice (1976) parameter } \\ \text { (defined in fig. 5, eq. 1) }\end{gathered}$

Figure 6. Springer and Gelhar (1991) method for measuring hydraulic conductivity showing (A) a plot of response data with various type curves and (B) the solution equations (eqs. 4, 5,6, and 7). 
damping imposed on the displaced water level by the well geometry and the material anisotropy (Zlotnik and McGuire, 1998) and is analogous to the damping constant used in damped-spring equations. Type curves were generated for several values of $F_{0}$ using the three possible regions of the damped-spring equation (fig. 6B) - overdamped (nonoscillatory, $\mathrm{F}_{0}$ greater than 2.0 ) (eq. 4), critically damped (transition, $F_{0}$ equals 2.0 ) (eq. 5), and underdamped (oscillatory, $F_{0}$ less than 2.0) (eq. 6) -as defined by Zlotnik and McGuire (1998). The type curves then were matched against the observed response (fig. 6A). The $F_{0}$ value corresponding to the type curve that best matched the response then was used to measure $K_{h}$ (fig. 6B, eq. 7). For example, the type curve that best matched the observed response in figure $6 \mathrm{~A}$ corresponded to an $F_{0}$ value of 0.5 , which was used in equation 7 (fig. 6B) to measure $\mathrm{K}_{\mathrm{h}}$.

Like the measurements derived from the Bouwer and Rice (1976) method, the Springer and Gelhar (1991) method was modified to account for anisotropic conditions using the Zlotnik method (1994). The $r_{w}{ }^{*}$ term (fig. 5B, eq. 3) was used in place of $r_{W}$ to compute the Bouwer and Rice parameter $\ln \left(R_{e} / r_{w}{ }^{*}\right)$ (fig. 5B, eq. 1), which was used in the Springer and Gelhar solution equation (fig. 6B, eq. 7). $\mathrm{K}_{\mathrm{h}}$ measurements were computed for anisotropy ratios $\left(\mathrm{K}_{\mathrm{h}} / \mathrm{K}_{\mathrm{v}}\right)$ of 1 and 10.

\section{Uncertainty with Selected Responses}

Some of the tests had conditions that reduced confidence in the derived $K_{h}$ values. The factors leading to this uncertainty included assumptions in determining the static water level, inadequate waterlevel recovery, and complex nonlinear effects of a given response. The $\mathrm{K}_{\mathrm{h}}$ values derived from some tests were assigned an uncertainty factor of \pm 0.2 orders of magnitude (50 to 200 percent of the observed value), while others were omitted altogether. Although the magnitude of the factor was selected arbitrarily, a technique was needed to assign uncertainty to certain $\mathrm{K}_{\mathrm{h}}$ measurements, and the chosen uncertainty factor produced a reasonable range around the measured value of $\mathrm{K}_{\mathrm{h}}$.

Although it may be inherent in all slug tests, uncertainty was assigned to measurements where the test conditions were not optimal, to emphasize the adverse nature of the test. An uncertainty factor of
0.2 orders of magnitude was assigned to the $\mathrm{K}_{\mathrm{h}}$ measurement when (1) the static water level was assumed, (2) the water level recovered to 50 percent or less of static level, and (3) the response curve did not match well with any of the Springer and Gelhar (1991) type curves. For a given test, the uncertainty factor was applied for each of the conditions listed, which produced some tests with an uncertainty factor of 0.4 orders of magnitude. Because the conditions of the slug tests performed in low conductivity formations were not optimal (conditions 1 and 2), a minimum recording limit of $0.01 \mathrm{ft} / \mathrm{d}$ (foot per day) for $K_{h}$ was assumed for the slug-test design.

Measurements of $\mathrm{K}_{\mathrm{h}}$ were omitted when either of two conditions existed. The first involved slug tests with mechanical initiation that were performed where the water level was drawn down below the top of the screen. As the water level recovered, the effective length of screen through which water could flow changed. This variation in the effective screen length violated the conventional theory of the slug test (Bouwer and Rice, 1976). For tests in which the water level eventually rose above the top of the screen, the test was considered to begin when the screen became fully saturated. For two tests in which the water level never rose above the top of the screen, no measurements of $\mathrm{K}_{\mathrm{h}}$ were derived.

The other condition under which measurements were omitted involved tests in highly conductive zones. Although the well was designed to minimize the effects of friction on the responses, it was impossible to remove them completely, and these effects became more significant as the water level recovered more rapidly. Friction effects could be detected by comparing measurements derived from each of the three displacements $(4,8$, and $12 \mathrm{in}$.) used in the pneumatic tests (Butler, 1998).

By isolating a $\mathrm{K}_{\mathrm{h}}$ threshold where friction effects became important, measurements above the threshold could be revised to reflect the measurement derived from the smallest displacement (which would be affected the least by friction). This threshold was determined to be at a $\mathrm{K}_{\mathrm{h}}$ of about $250 \mathrm{ft} / \mathrm{d}$. For measurements below this threshold, no difference between values derived from the different displacements was observed. However, for measurements above the threshold, a recognizable difference between the small displacement and the medium and large displacements was observed. Therefore, all of the 
medium and large displacements were omitted for the measurements above $250 \mathrm{ft} / \mathrm{d}$.

\section{Comparison of Horizontal Hydraulic Conductivity Data with Nearby Lithologic Descriptions}

It was important to separate the results of slug tests performed in the streambed from those where the screen may have penetrated into the aquifer or other material. For this reason, nearby lithology was characterized by compiling geologic logs. For sites near bridges, borehole data from bridge plans of the Nebraska Department of Roads provided general descriptions of the local lithology. At some sites, geologic test holes from the University of NebraskaLincoln, Conservation and Survey Division (UNL-CSD) provided detailed descriptions of nearby geology, although these test holes generally were farther from the site than the bridge boreholes. The bridge borehole descriptions were used as the primary means to characterize lithology because the UNL-CSD test holes did not provide information on the streambed materials and were generally too far away to be of practical use.

The distinction between streambed and nonstreambed materials was based on the interpretation of the borehole data. For cases where no clear boundary existed to separate the streambed from other materials, the $\mathrm{K}_{\mathrm{h}}$ measurements all were assumed to reflect streambed materials. This is especially true for the Platte River sites, where Quaternary alluvial deposits essentially consisting of the same materials as the streambed (Swinehart and others, 1994) underlie the streambed but overlie the Ogallala Formation. Although it often was possible to distinguish when cemented materials of the Ogallala Formation were being tested, it was nearly impossible to do the same for unconsolidated materials of the alluvial deposits and the Ogallala Formation. As a result, for these purposes, the streambed commonly was defined as the material above the uppermost cemented layer of the Ogallala Formation. Because these distinctions were subjective, summary statistics were computed for all of the $\mathrm{K}_{\mathrm{h}}$ measurements in addition to just the streambed $\mathrm{K}_{\mathrm{h}}$ measurements. Individual measurements are given in the Appendix of this report.

\section{HYDRAULIC CONDUCTIVITY PROFILES}

After the slug-test responses were collected and analyzed, profiles of $\mathrm{K}_{\mathrm{h}}$ were developed for each site and compared to nearby lithology when available. Although both isotropic and anisotropic values were determined (table 2), the profiles were developed from isotropic $\mathrm{K}_{\mathrm{h}}$ values, and lithologic comparisons and other discussion of the profiles also pertain to isotropic conditions. When possible, distinctions were made between $\mathrm{K}_{\mathrm{h}}$ values of streambed material and nonstreambed material. The results from each site were summarized by computing the minimum, harmonic mean (Freeze and Cherry, 1979), arithmetic mean, maximum, and standard deviation for streambed measurements only and for all measurements in each profile (table 2). Because the measurements ranged over several orders of magnitude, the standard deviation of the logarithm of $\mathrm{K}_{\mathrm{h}}$ also was computed for each site.

\section{Platte River Watershed}

There were 10 sites in the Platte River watershed, of which 5 main-stem sites were on either the Platte River or the South Platte River. The streambed at the main-stem sites yielded $\mathrm{K}_{\mathrm{h}}$ values that generally ranged from 100 to $1,000 \mathrm{ft} / \mathrm{d}$. In central Nebraska, layers of sand cemented with calcium carbonate form mortar beds that are part of the Ogallala Formation (Dreeszen and others, 1973). These mortar beds commonly occur at the top of the formation and were probably the cause of refusal at four of the five mainstem sites. The five other sites did not have the same similarity in $\mathrm{K}_{\mathrm{h}}$ ranges, with measurements ranging from $490 \mathrm{ft} / \mathrm{d}$ at the PS site to less than $0.01 \mathrm{ft} / \mathrm{d}$ at the $\mathrm{PC}$ and $\mathrm{BC}$ sites. The most homogeneous profile occurred at the NM site and the most varied profile occurred at the $\mathrm{BC}$ site.

\section{Ninemile Creek near Minatare}

The $K_{h}$ profile at the NM site (fig. 7) did not vary greatly from its mean isotropic value of $91 \mathrm{ft} / \mathrm{d}$ (table 2). Although no bridge borehole data existed to provide insight into the materials being tested, a UNL-CSD test hole about $2 \mathrm{mi}$ (miles) away and at an elevation similar to the study site indicated sand and gravel to a depth of $196 \mathrm{ft}$ (Sibray and Smith, 2000; UNL-CSD test hole 32-37). It was assumed that all of 


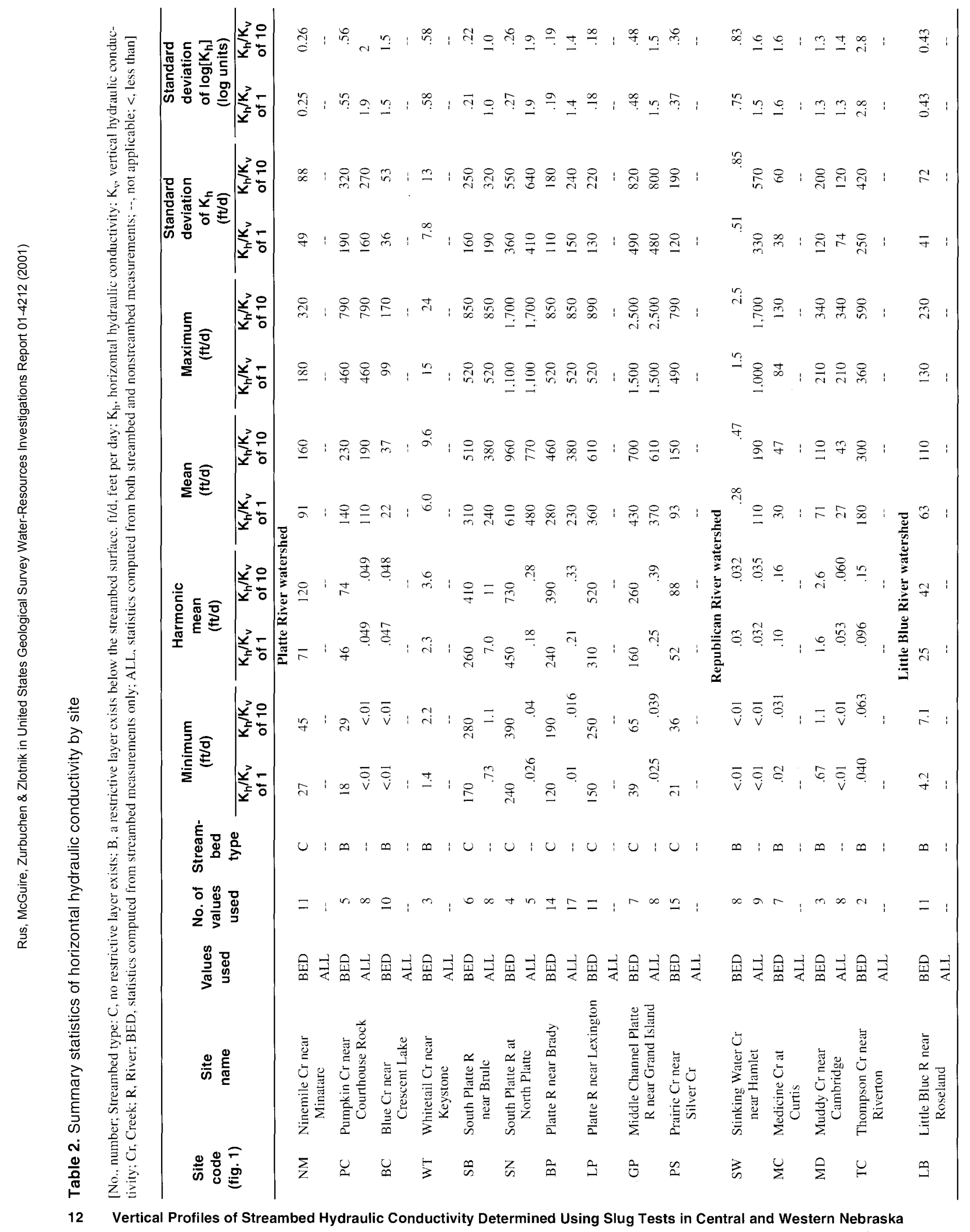




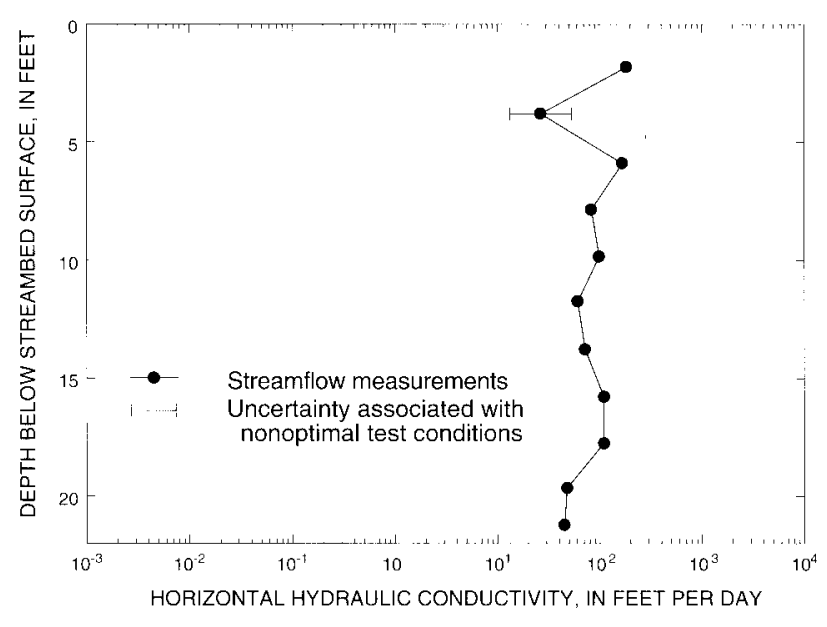

Figure 7. Profile of hydraulic conductivity, Ninemile Creek near Minatare (site NM).

the depths tested were part of the streambed, and summary statistics were computed accordingly (table 2).

\section{Pumpkin Creek near Courthouse Rock}

Based on the lithologic evidence, the $\mathrm{K}_{\mathrm{h}}$ profile for the PC site (fig. 8A) appeared to reflect streambed materials to a depth of $12 \mathrm{ft}$. Bridge boreholes (fig. 8B) on the top of the left bank (when looking downstream) (borehole 1) and the top of the right bank (borehole 2) indicated that the Brule Formation was somewhere between 7 and $19 \mathrm{ft}$ below the streambed surface (Nebraska Department of Roads, unpublished data for bridge number S088-05357, 1990). The Brule Formation consists of siltstone with fractured areas that yield large volumes of water to wells along the Pumpkin Creek Valley (Verstraeten and others, 1995) and was not considered part of the streambed. The low $\mathrm{K}_{\mathrm{h}}$ measurement at a depth of $12 \mathrm{ft}$ probably indicated the presence of redeposited Brule Formation sediments, and the much higher isotropic measurement of $220 \mathrm{ft} / \mathrm{d}$ at the next depth may have been the result of fractures within the Brule Formation. As a result, the measurements from depths below $12 \mathrm{ft}$ were considered nonstreambed for the purposes of the summary statistics (table 2).

\section{Blue Creek near Crescent Lake}

The $\mathrm{K}_{\mathrm{h}}$ measurements for the $\mathrm{BC}$ site ranged over several orders of magnitude, with a minimum value less than $0.01 \mathrm{ft} / \mathrm{d}$ (fig. $9 \mathrm{~A}$ ). Although no borehole logs were available at the site (fig. 9B), a UNLCSD test hole $1 \mathrm{mi}$ away indicated several layers of silt interspersed with sand underlying the area (Smith and Swinehart, 2000; UNL-CSD test hole 16-B-72). Not enough supporting evidence was available to determine whether or not the profile extended below the streambed; therefore, all data points were considered as part of the streambed for the summary statistics (table 2).
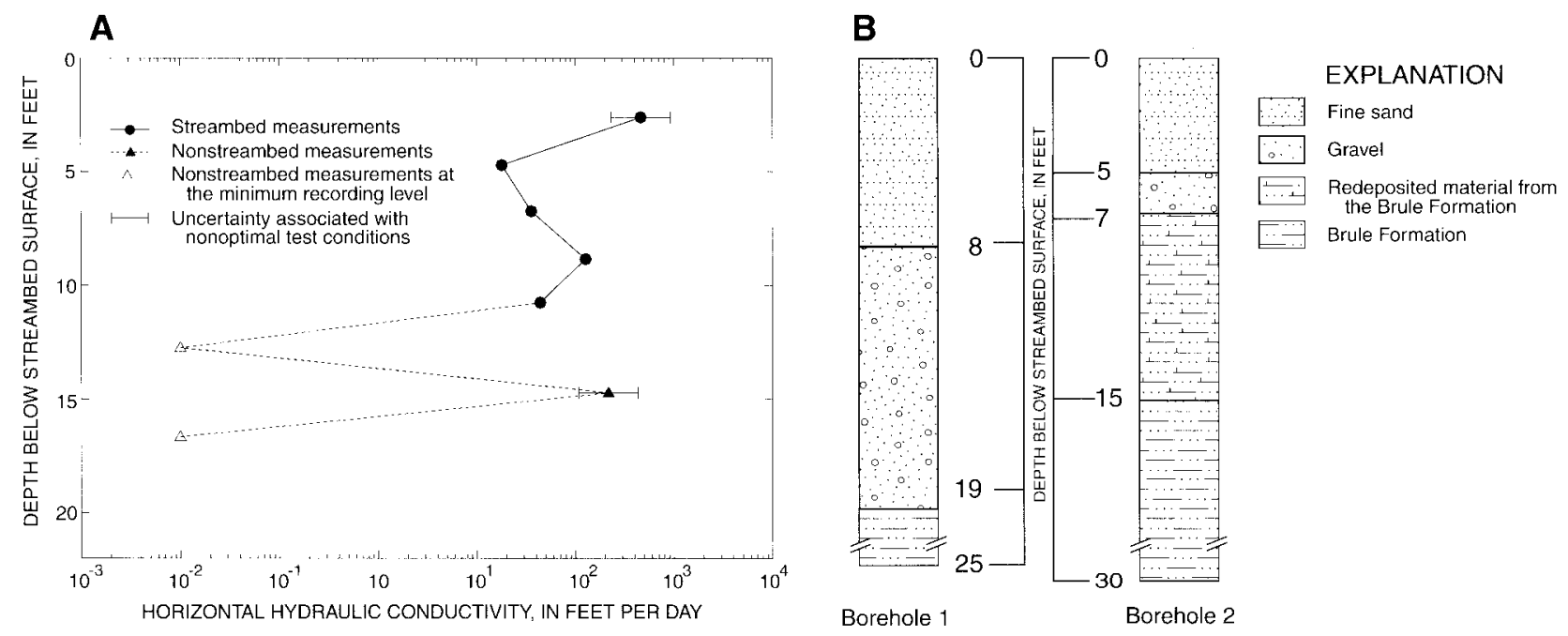

Figure 8. Profile of $(A)$ hydraulic conductivity and $(B)$ basic lithology from a nearby bridge borehole, Pumpkin Creek near Courthouse Rock (site PC). 


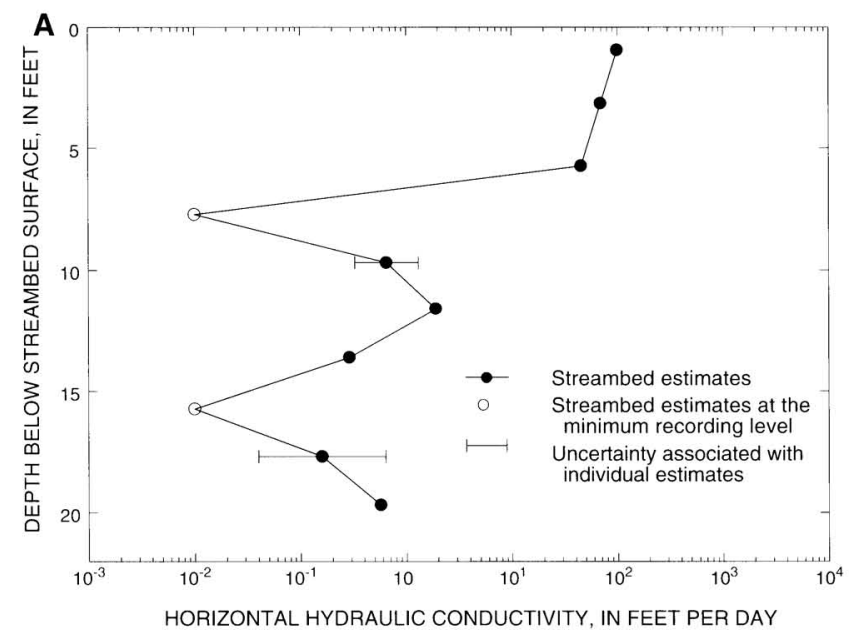

B

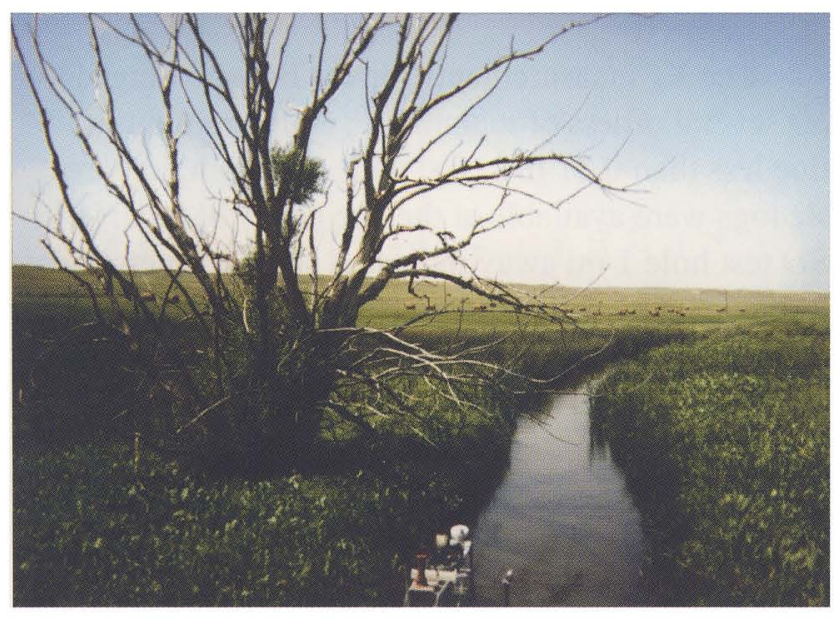

Figure 9. (A) Hydraulic conductivity profile and (B) photograph of the Blue Creek study site near Crescent Lake (Site $B C)$.

\section{Whitetail Creek near Keystone}

Limited lithologic data were available to compare to the WT profile (fig. 10). No bridge borehole existed at the site, but a UNL-CSD test hole about 3.5 mi downstream indicated layers of sand and gravel interbedded with thin layers of clay to a depth of $70 \mathrm{ft}$ below land surface (Diffendal and Goeke, 2000; UNLCSD test hole 9-K-34). Fine sand was observed at the streambed surface, which may be reflected in the $\mathrm{K}_{\mathrm{h}}$ measurements of the profile. However, an impenetrable layer was contacted at a depth of $5 \mathrm{ft}$ that could not be explained from the limited lithologic data avail- able. This layer was detected by probing the streambed with a 0.25 -in.-diamater rod at several points in the stream within a $500-\mathrm{ft}$ radius of the site. Although the composition of this layer was unknown, it probably would not be included as part of the streambed, and the profile and summary statistics (table 2) probably represent the streambed $K_{h}$ adequately.

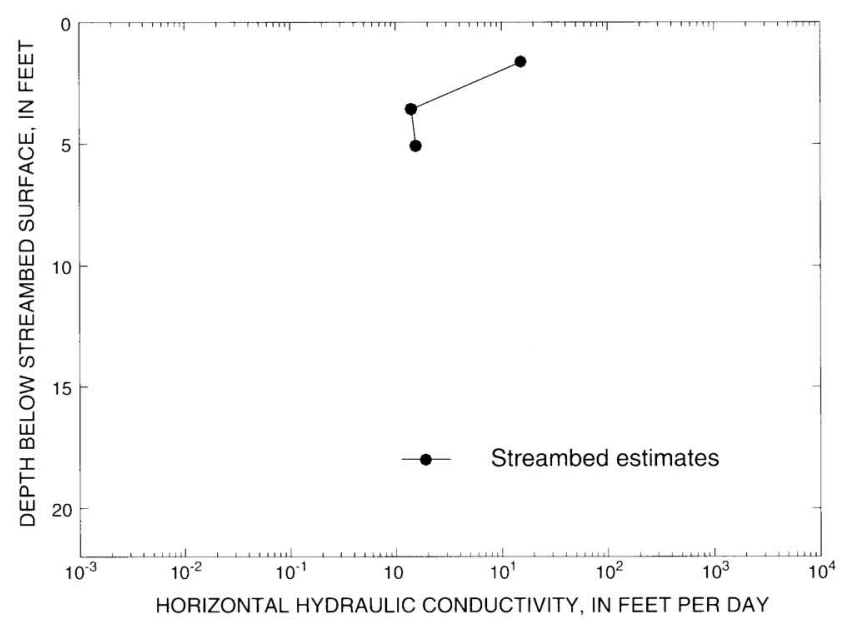

Figure 10. Profile of hydraulic conductivity, Whitetail Creek near Keystone (site WT).

\section{South Platte River near Brule}

The profile at the SB site showed highly conductive materials to a depth of $13 \mathrm{ft}$ (fig. 11A); below $13 \mathrm{ft}$, low $\mathrm{K}_{\mathrm{h}}$ measurements may correspond to a mortar bed in the Ogallala Formation. A nearby bridge borehole indicated a layer of cemented silts and sands $28 \mathrm{ft}$ below the streambed surface (fig. 11B) (Nebraska Department of Roads, unpublished data for bridge number SL51A-00068, 1976). These materials were consistent with the cemented clays and sands found at the top of the Ogallala Formation at a UNL-CSD test hole about $2 \mathrm{mi}$ upstream from the site (Diffendal and Goeke, 2000; UNL-CSD test hole 20-A-49). It was assumed that the measurements for the profile below $13 \mathrm{ft}$ were associated with cemented material because they were much lower than would be expected for sand and gravel and because the slug-test system could not penetrate the material. Therefore, the measurements from the bottom two depth intervals were not included as part of the streambed for the summary statistics (table 2). 
A

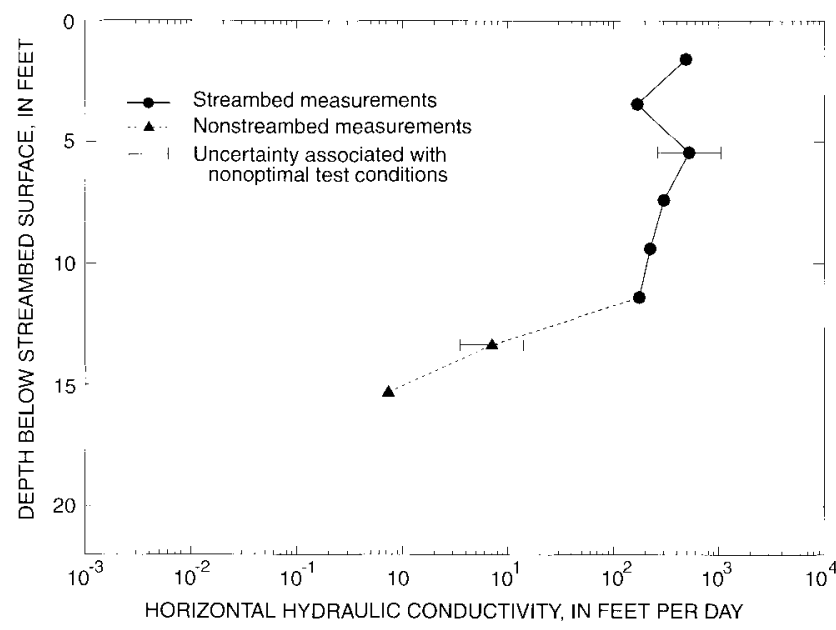

B

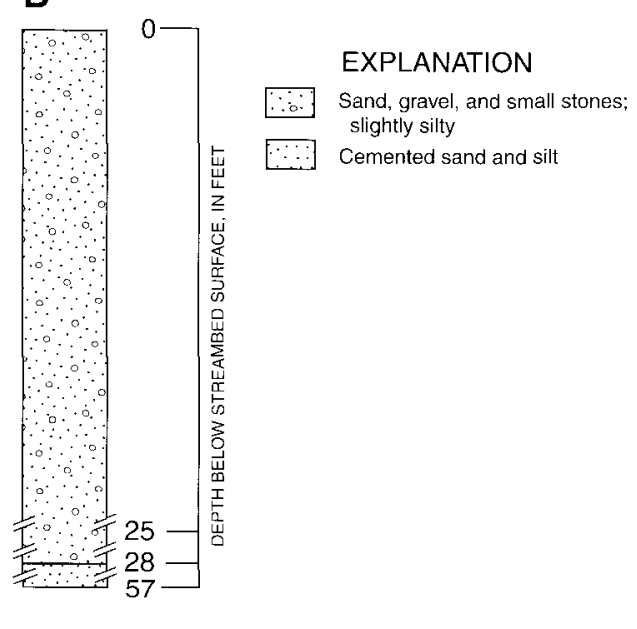

Figure 11. Profile of $(A)$ hydraulic conductivity and $(B)$ basic lithology from a nearby bridge borehole, South Platte River near Brule (site SB).

\section{South Platte River at North Platte}

Like the SB site, the measurements of $\mathrm{K}_{\mathrm{h}}$ at the SN site were relatively high (fig. 12A) until what seemed to be a mortar bed at the top of the Ogallala Formation was reached. A borehole at a nearby bridge indicated cemented material about $7 \mathrm{ft}$ below the streambed surface (fig. 12B) (Nebraska Department of Roads, unpublished data for bridge number S08308198L, 1972). Additionally, the lithologic description of a UNL-CSD test hole located about $0.1 \mathrm{mi}$ from the site indicated cemented sandstone at the top of the Ogallala Formation and at approximately the same elevation as that of the borehole (Goeke, 2000;
UNL-CSD test hole 13-TP-99). Because the slug-test system could not penetrate the material at a depth of $9 \mathrm{ft}$ and because the $\mathrm{K}_{\mathrm{h}}$ measurement at that depth was so much lower than at the overlying depths, the bottom depth interval was not considered part of the streambed for the summary statistics (table 2).

\section{Platte River near Brady}

Two sets of slug tests were performed at the BP site, resulting in two different profiles (fig. 13A). Both reached a low- $\mathrm{K}_{\mathrm{h}}$ layer that may have been a mortar bed of the Ogallala Formation, according to a nearby bridge borehole (fig. 13B) (Nebraska Department of
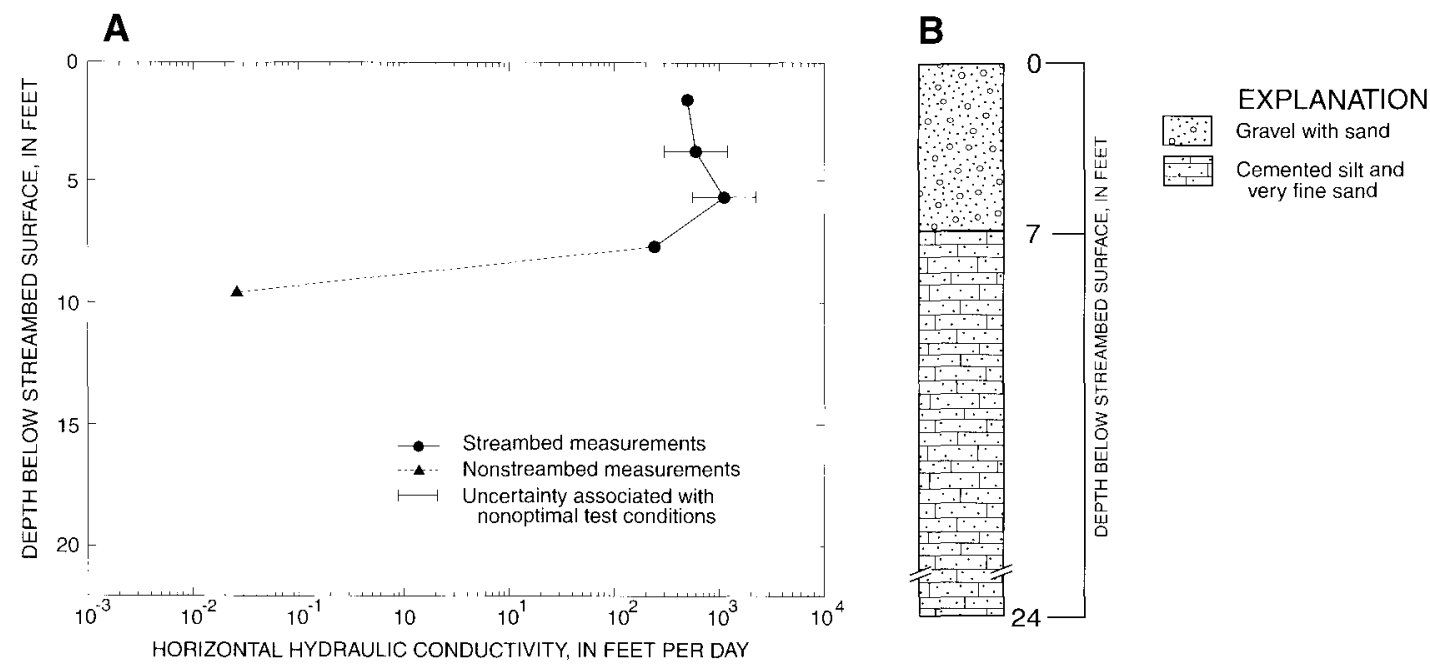

Figure 12. Profile of (A) hydraulic conductivity and $(B)$ basic lithology from a nearby bridge borehole, South Platte River at North Platte (site SN). 
A

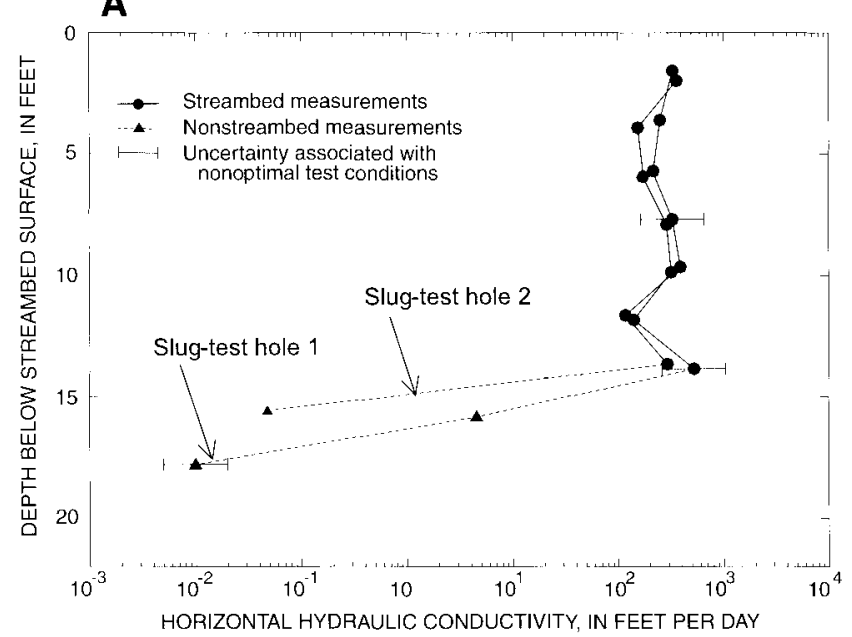

B

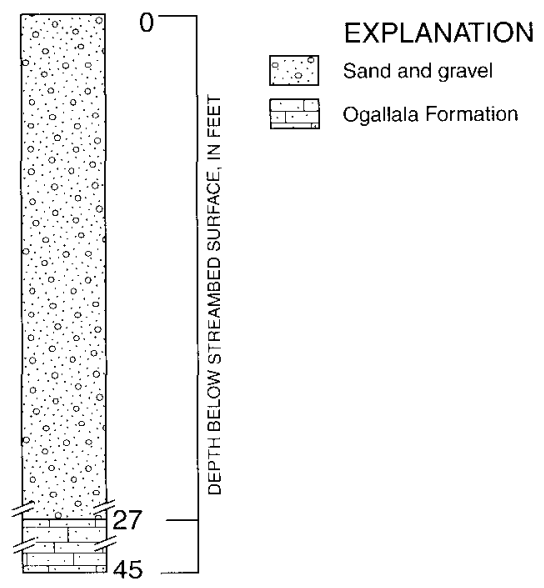

Figure 13. Profile of (A) hydraulic conductivity and (B) basic lithology from a nearby bridge borehole, Platte River near Brady (site BP).

Roads, unpublished data for bridge number SS56A-00115, 1980). At the time of testing, the channel was $474 \mathrm{ft}$ wide, and slug-test holes 1 and 2 were approximately 430 and $190 \mathrm{ft}$ from the left bank (if looking downstream), respectively. Relatively little variation was evident between the two holes, with both profiles indicating similar trends. In both cases, an impenetrable layer was contacted at a depth of 15 to $18 \mathrm{ft}$ below the streambed surface. Although the nearest bridge borehole was almost 4 mi upstream from the site, the data indicated that the Ogallala Formation was present at a depth of $27 \mathrm{ft}$ (fig. 13B). A nearby UNL-CSD test hole indicated cemented silt and sand at the top of the Ogallala Formation (Goeke, 2000; UNL-CSD test hole 20-H-78). It is reasonable to assume that the formation may have been shallower at the study site, and that it may have included a mortar bed layer at the surface, which resulted in the low $\mathrm{K}_{\mathrm{h}}$ values observed. For these reasons, the measurements derived from depths below $15 \mathrm{ft}$ were not considered as part of the streambed. Summary statistics were computed for the site by combining the results from both slug-test holes (table 2).

\section{Platte River near Lexington}

The profile that was derived for the LP site (fig. 14A) presumably reflected the sand and gravel expected in the streambed of the Platte River. Although a nearby bridge borehole (fig. 14B) indi-
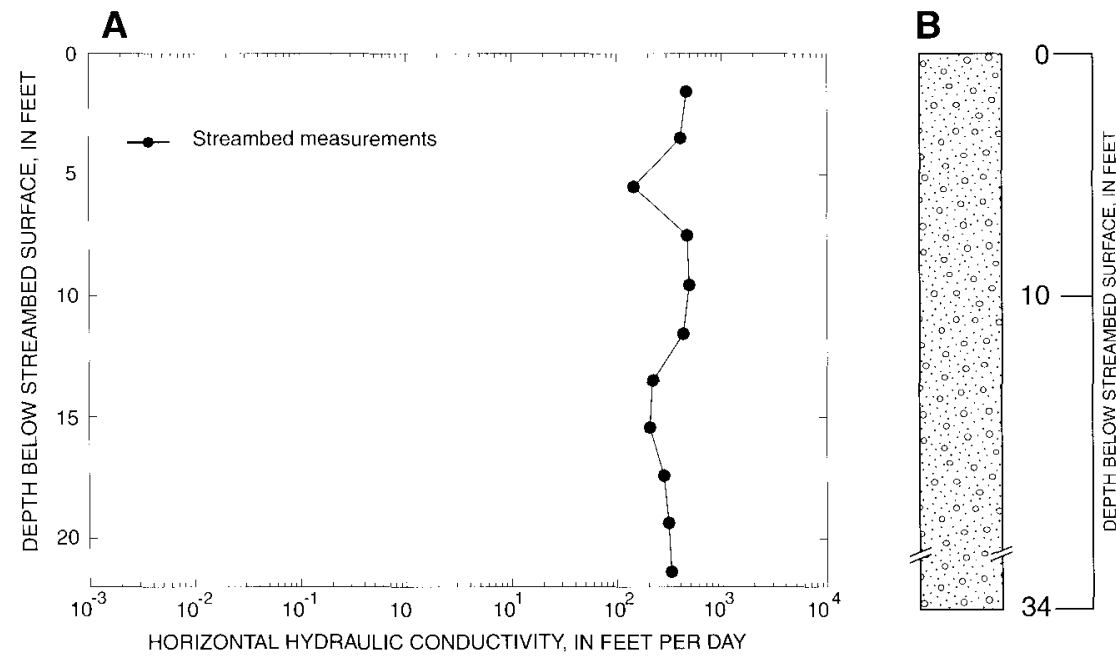

\section{EXPLANATION}

Gravel and sand; sediment grades from fine sand on top to coarse gravel on the bottom

Figure 14. Profile of (A) hydraulic conductivity and (B) basic lithology from a nearby bridge borehole, Platte River near Lexington (site LP). 
cated the material grades from fine sand near the surface to coarse gravel with depth (Nebraska Department of Roads, unpublished data for bridge number S283-05534, 1963), the $K_{h}$ profile did not vary far from its mean isotropic value of $360 \mathrm{ft} / \mathrm{d}$ (table 2), and the standard deviation of the logarithm of $K_{h}$ was 0.18 , which was the smallest of all the profiles. Although not shown in figure 14B, the bridge borehole data indicated slightly cemented sand beginning $34 \mathrm{ft}$ below the streambed surface, which was probably a mortar bed. A nearby UNL-CSD test hole indicated that a mortar bed existed at the top of the Ogallala Formation (Smith, 1999; UNL-CSD test hole 33-U-41). It is probable that the materials tested, which were above the mortar bed, were all part of the streambed; therefore, all of the measurements were used to compute summary statistics (table 2 ).

\section{Middle Channel Platte River near Grand Island}

At the GP site, an impenetrable layer was reached approximately $15 \mathrm{ft}$ below the streambed. The corresponding profile (fig. 15A) shows the difference in $\mathrm{K}_{\mathrm{h}}$ value of the material at this depth with those of the materials above it. A general lithologic description from a bridge borehole nearby (Nebraska Department of Roads, unpublished data for bridge number C04004125,1976 ) indicates that a 3 -ft-thick layer of silt exists below $15 \mathrm{ft}$ of sand and gravel (fig. 15B). Because streambed material in the Platte River does not commonly include fine-grained materials such as silt (Kircher, 1981), it was assumed that the silt layer was not part of the streambed material, and summary statistics were computed accordingly (table 2).

\section{Prairie Creek near Silver Creek}

The entire profile at the PS site (fig. 16A) appeared to represent streambed materials, which were composed of silty sand, sand, and gravel according to bridge borehole data nearby (fig. 16B) (Nebraska Department of Roads, unpublished data for bridge number S039-01099, 1993). It was believed that the silt layer shown at a depth of $20 \mathrm{ft}$ on the bridge borehole was not contacted by the slug-test system because the isotropic $\mathrm{K}_{\mathrm{h}}$ measurement at that depth was $53 \mathrm{ft} / \mathrm{d}$, which is larger than the representative value of $0.3 \mathrm{ft} / \mathrm{d}$ given for silt (Todd, 1980). All values measured were considered as part of the streambed and were used to compute summary statistics for the site (table 2).
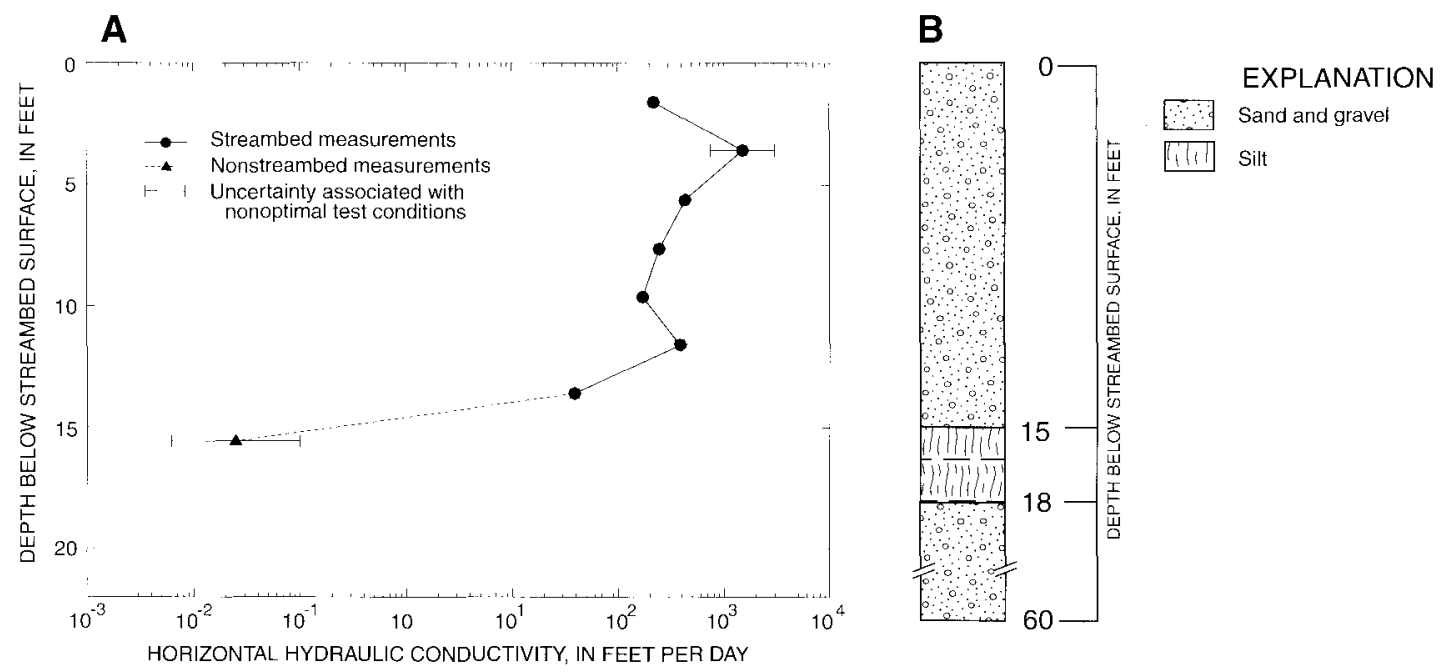

Figure 15. Profile of (A) hydraulic conductivity and (B) basic lithology from a nearby bridge borehole, Middle Channel Platte River near Grand Island (site GP). 


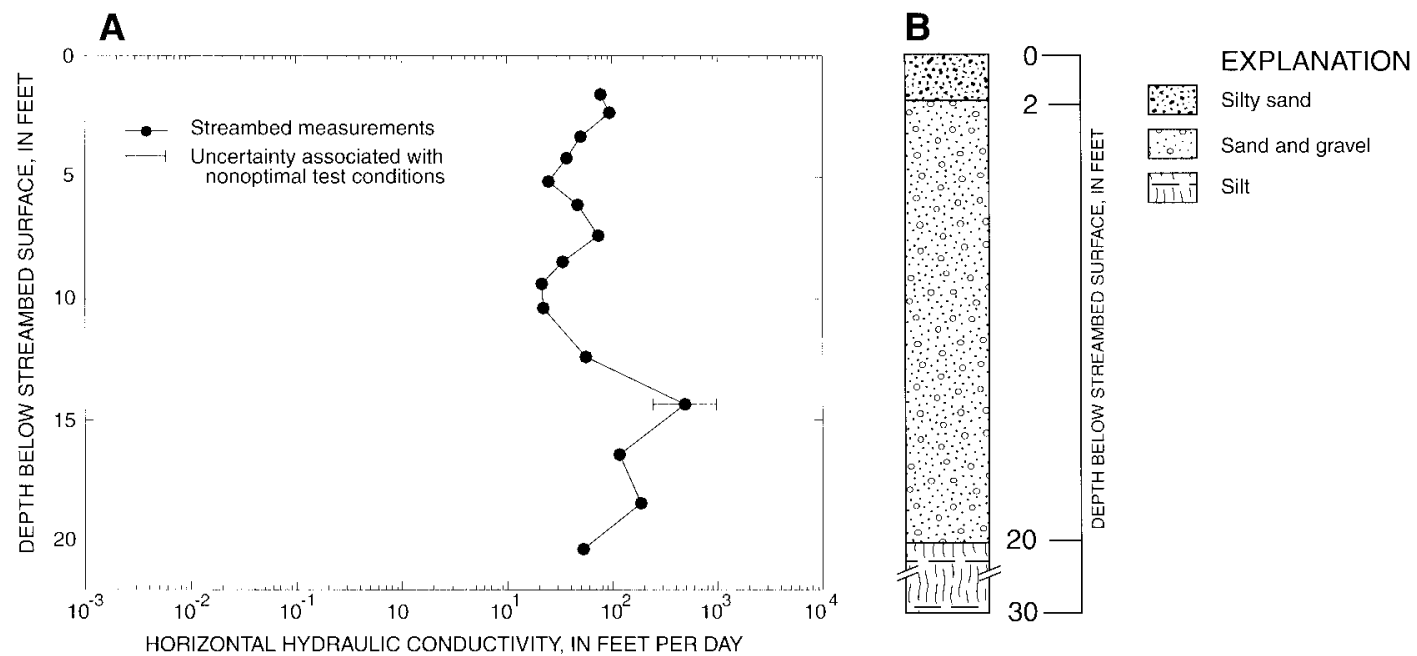

Figure 16. Profile of (A) hydraulic conductivity and (B) basic lithology from a nearby bridge borehole, Prairie Creek near Silver Creek (site PS).

\section{Republican River Watershed}

Four sites in the Republican River watershed were evaluated, all of which were on tributaries to the Republican River. At each of the four sites, the $\mathrm{K}_{\mathrm{h}}$ profiles varied widely.

\section{Stinking Water Creek near Hamlet}

The profile at the SW site (fig. 17A) appeared to show a restrictive streambed layer overlying more conductive materials. Although a bridge borehole was not available at the site, a UNL-CSD test hole next to a bridge $1.5 \mathrm{mi}$ downstream indicated silty clays overlying loose sand (Eversoll, 2000; UNL-CSD test hole 8-SW-33) (fig. 17B). A geologic section of the Stinking Water Creek Valley $2.5 \mathrm{mi}$ upstream from the site indicated a layer of sand and gravel representing a buried channel beneath a layer of silt (Waite and others, 1946). It was presumed that this buried-channel material was contacted at the bottom depth interval of the profile; thus, the $\mathrm{K}_{\mathrm{h}}$ measurement from that depth was not considered as part of the streambed for summary statistics (table 2 ).

\section{Medicine Creek at Curtis}

The profile at the MC site (fig. 18A) did not seem to correspond to the lithologic description given by a bridge borehole at the site (fig. 18B) (Nebraska Department of Roads, unpublished data for bridge number S018-00036, 1949). The streambed appeared to alternate between materials with $K_{h}$ ranging from 10 to $100 \mathrm{ft} / \mathrm{d}$ and materials with $\mathrm{K}_{\mathrm{h}}$ ranging from 0.01 to $0.1 \mathrm{ft} / \mathrm{d}$. However, the lithologic description for the borehole indicated materials that graded from sandy loams near the surface to coarse gravel and boulders with depth. Material that could not be penetrated by the well was contacted approximately $12 \mathrm{ft}$ below the streambed surface. Although both the $\mathrm{K}_{\mathrm{h}}$ profile and lithologic log provide details about the material below the streambed surface, not enough information was available to determine whether or not nonstreambed materials were being tested; thus, all of the measurements were used in the summary statistics (table 2).

\section{Muddy Creek near Cambridge}

At the MD site, the lithologic profile (fig. 19B) developed from a bridge borehole $0.5 \mathrm{mi}$ upstream (Nebraska Department of Roads, unpublished data for bridge number C037-04205,1984) suggested that the materials tested in the $\mathrm{K}_{\mathrm{h}}$ profile (fig. 19A) below a 6-ft depth were part of the Ogallala Formation rather than the streambed. The streambed thickness may have varied between the slug-test site and the borehole. However, an outcrop of what probably is the Ogallala Formation was observed above water level at the site (fig. 20). Several other outcrops of the Ogallala Formation occur along Muddy Creek (Eversoll and others, 1988), suggesting that the stream may be incised into the formation. Summary statistics were computed for the streambed measurements and for all of the $\mathrm{K}_{\mathrm{h}}$ measurements (table 2). 
A

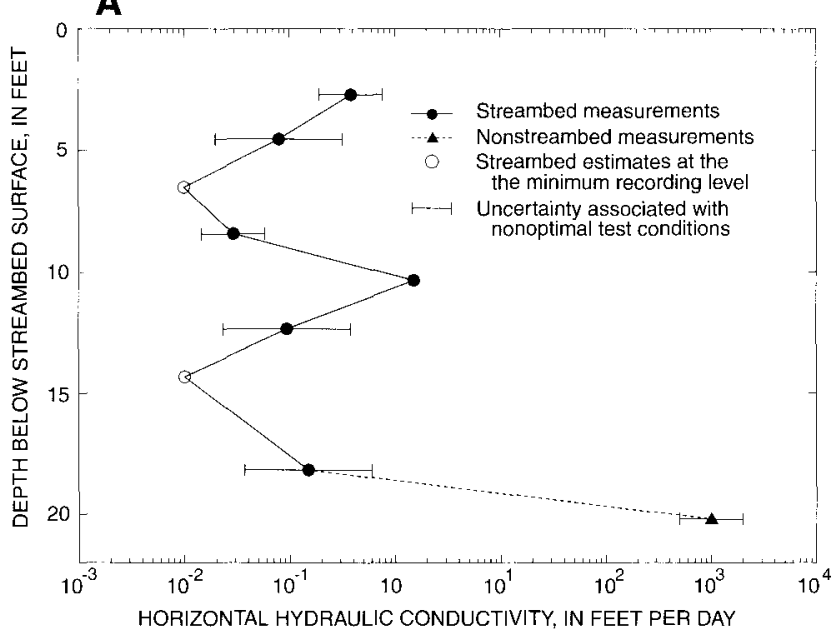

B

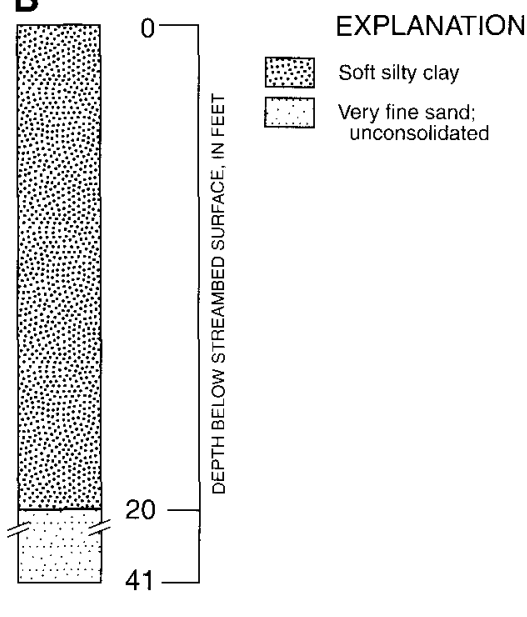

Figure 17. Profile of (A) hydraulic conductivity and (B) basic lithology from a nearby test hole, Stinking Water Creek near Hamlet (site SW).

A

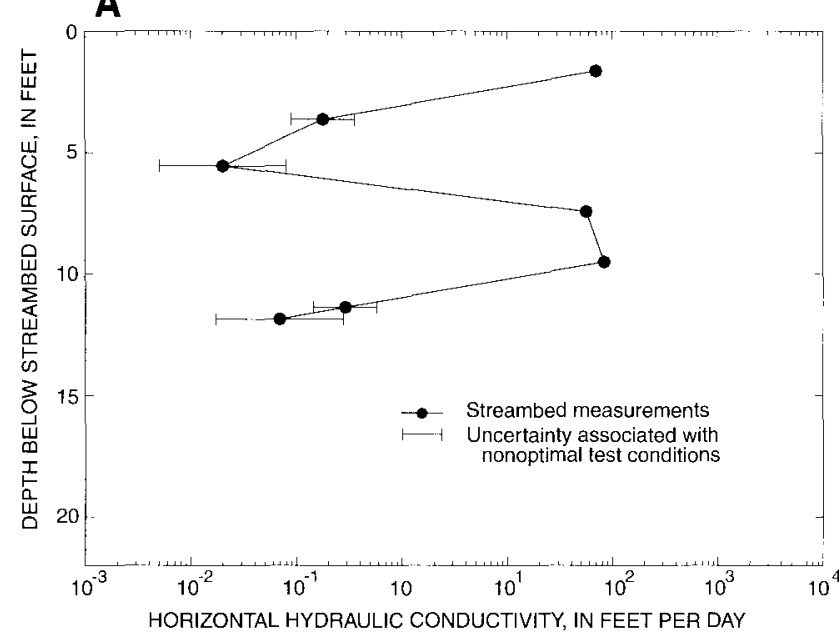

B

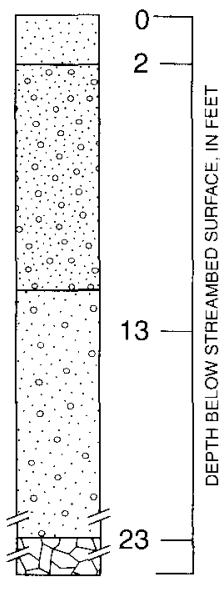

EXPLANATION

Sandy loam

Fine sand to light gravel

$\therefore$ Coarse gravel

(7) Rocks and boulders

Figure 18. Profile of (A) hydraulic conductivity and $(B)$ basic lithology from a nearby bridge borehole, Medicine Creek at Curtis (site MC)

A

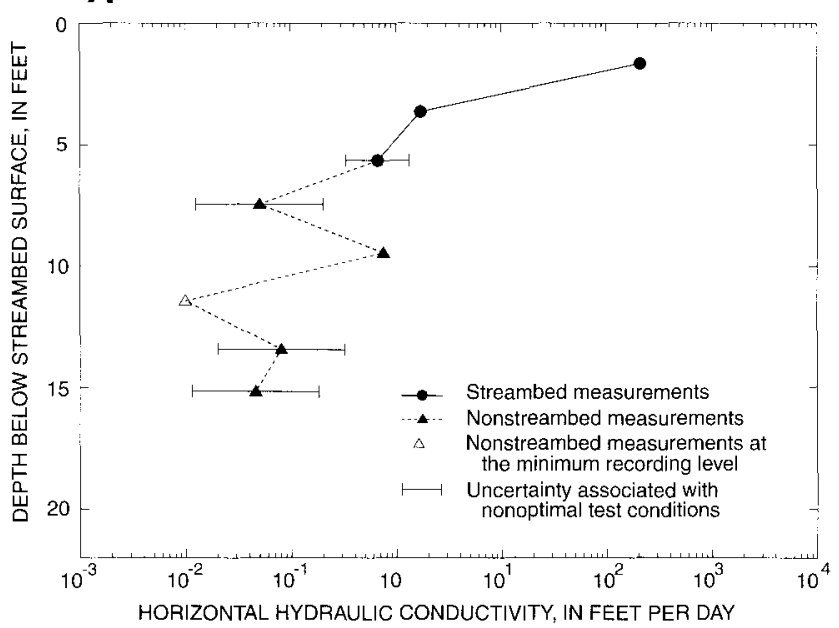

B

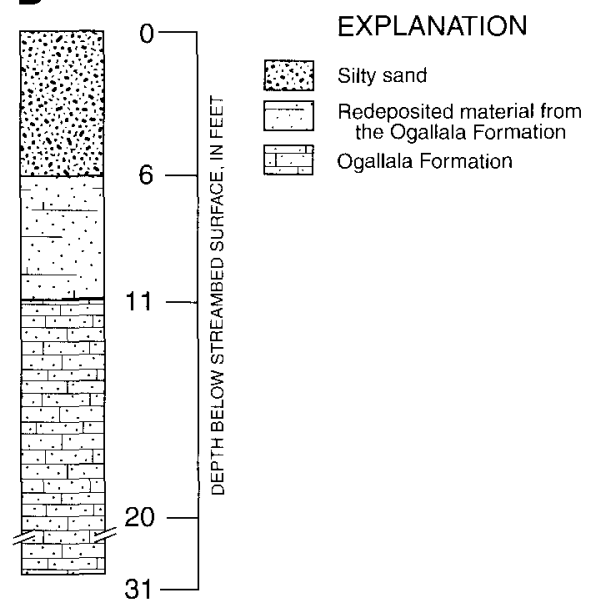

Figure 19. Profile of $(A)$ hydraulic conductivity and $(B)$ basic lithology from a nearby bridge borehole, Muddy Creek near Cambridge (site MD). 


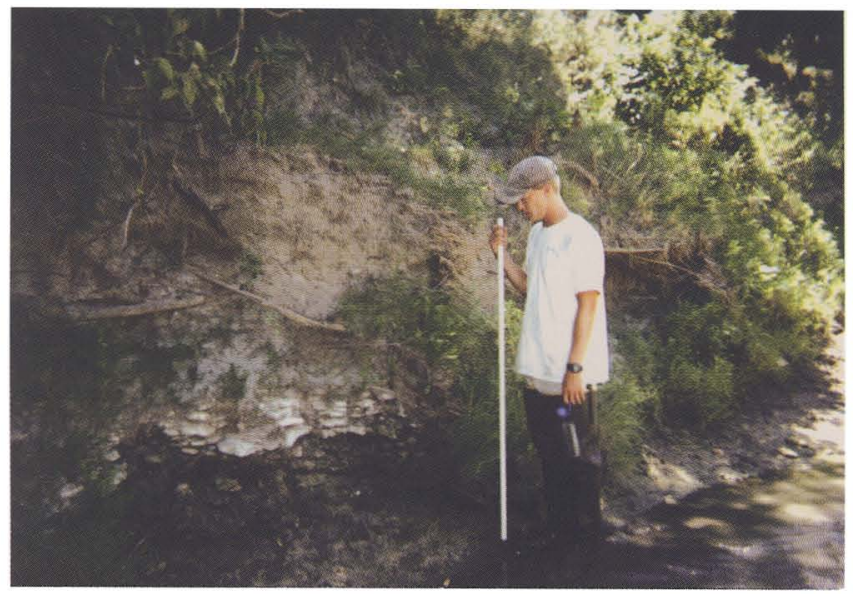

Figure 20. Outcrop of probable Ogallala Formation near the MD site.

\section{Thompson Creek near Riverton}

The $\mathrm{K}_{\mathrm{h}}$ profile at the TC site (fig. $21 \mathrm{~A}$ ) demonstrated the relatively large values associated with sands at the surface of the streambed as well as the small values that likely corresponded to a clay layer underneath (fig. 21B). Unfortunately, $\mathrm{K}_{\mathrm{h}}$ measurements were derived down to a depth of only $3 \mathrm{ft}$. Although a third depth of $5 \mathrm{ft}$ was tested using a mechanical slug test, the water level recovered only 0.25 in. from a $6.0-\mathrm{ft}$ displacement over 20 minutes and did not rise above the top of the screen. Bridge borehole data from the site showed coarse sand and gravel below a clay layer at a depth of $12 \mathrm{ft}$ below the streambed surface (fig. 21B) (Nebraska Department of Roads, unpublished data for bridge number C031-22805, 1986). Geologic sections of the area indicated that the sand and gravel is part of an extensive geologic formation (Waite and others, 1946) rather than modern streambed materials. Although the profile did not extend into the coarse sand and gravel, it is reasonable to assume that the streambed consisted only of the fine sand and clay layers; thus the summary statistics (table 2) probably represent the streambed adequately.

\section{Little Blue River Watershed}

\section{Little Blue River near Roseland}

Despite a nearby borehole log indicating that the streambed is composed of fine sand and gravel with silty clay layers (fig. 22B) (Nebraska Department of Roads, unpublished data for bridge number $\mathrm{C001-}$ 01905, 1978), the profile of $\mathrm{K}_{\mathrm{h}}$ at the LB site did not vary outside of the 10 to $100 \mathrm{ft} / \mathrm{d}$ range until a depth of $17 \mathrm{ft}$ below the streambed surface was tested (fig. 22A). The $\mathrm{K}_{\mathrm{h}}$ of the silty clay was expected to be quite small (less than $0.3 \mathrm{ft} / \mathrm{d}$ ), whereas the minimum value expected for gravel was $280 \mathrm{ft} / \mathrm{d}$ (Freeze and Cherry, 1979). Even though the screened interval was only 8 in., it was probable that a mixture of the two materials was being tested, resulting in the range of values observed. Because inadequate information was available to determine whether or not aquifer materials
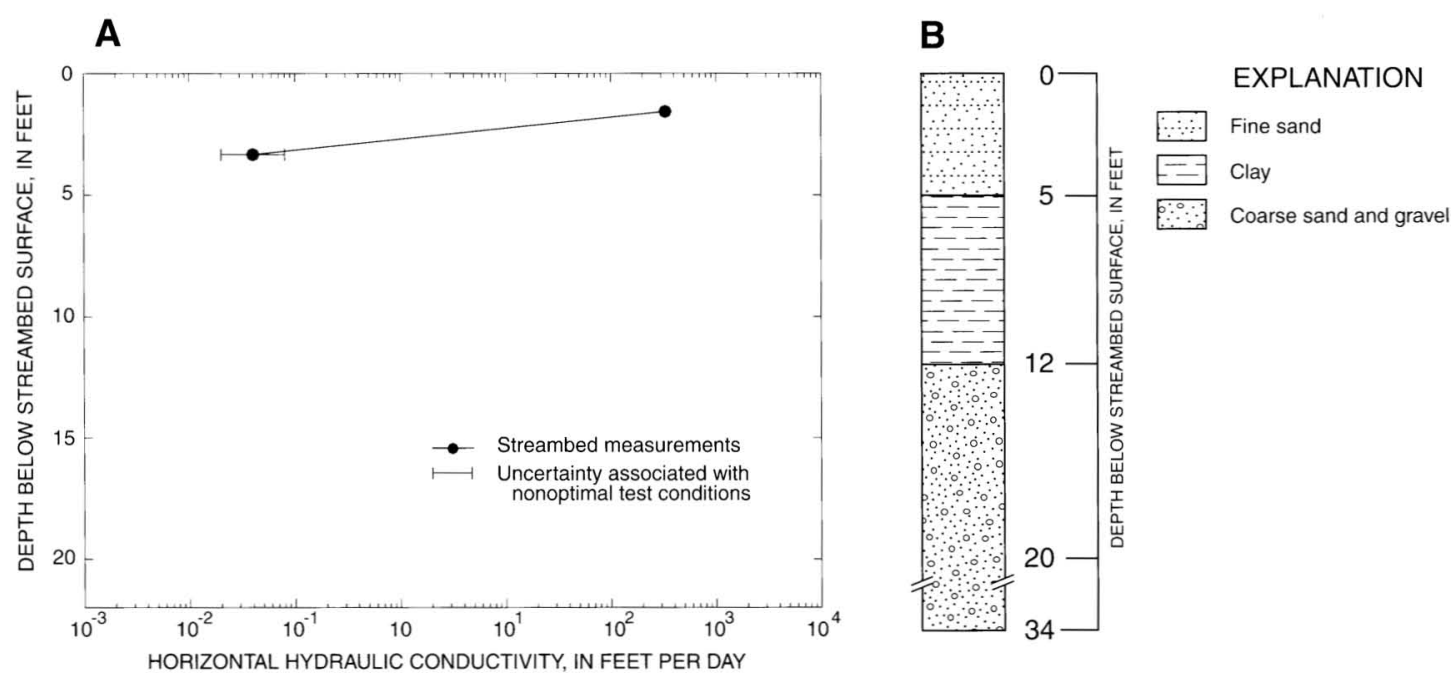

Figure 21. Profile of (A) hydraulic conductivity and (B) basic lithology from a nearby test hole, Thompson Creek near Riverton (site TC). 
A

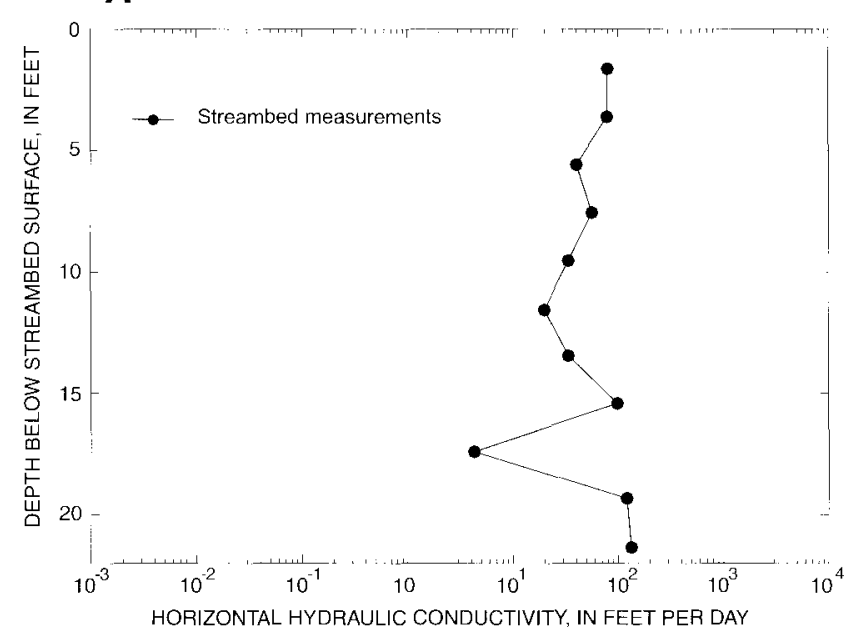

B

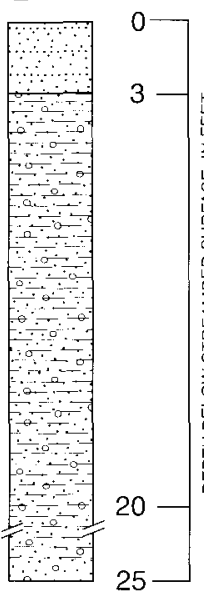

EXPLANATION

Fine sand with silty clay layers

Gravel with silty clay layers

Figure 22. Profile of $(A)$ hydraulic conductivity and (B) basic lithology from a nearby bridge borehole, Little Blue River near Roseland (site LB).

were being tested, all values were assumed to be part of the streambed and were summarized accordingly (table 2). The static water level in the well was equal to the surface-water level from 0 to $3.6 \mathrm{ft}$ below the streambed surface, but was $3.5 \mathrm{ft}$ lower than the surface-water level from $5.6 \mathrm{ft}$ below the bed to the bottom of the profile. It is possible that a silty clay layer exists between the depths of 3.6 and $5.6 \mathrm{ft}$ that restricted the flow of water between the ground and surface water, thus leading to the difference in water levels.

\section{Discussion of the Profiles}

Although the profiles appear to be adequate for assessing the $\mathrm{K}_{\mathrm{h}}$ of the streambed and its variability with depth at a point on a stream, they also show the variability among sites. This is important for studies requiring that the hydraulic conductivity of the streambed be defined, although limitations to the interpretation of the results still exist.

Although only one site was available with multiple $K_{h}$ profile data (BP), the similarity between the two profiles $240 \mathrm{ft}$ apart (fig. 13A) suggests that one profile may have been adequate to represent streambed $\mathrm{K}_{\mathrm{h}}$ at the site. Although the profiles often showed abrupt changes that may have corresponded to nonstreambed materials, the measurements of $K_{h}$ alone did not provide enough information to determine whether or not streambed materials were being tested.
Lithologic descriptions from nearby bridge boreholes were useful in estimating a reasonable vertical limit of the streambed materials.

Streambed $K_{h}$ varied with depth and between sites. The $K_{h}$ values with depth from 7 of the 15 sites varied over 3 orders of magnitude (fig. 23A). Out of the remaining eight sites, seven had profiles that showed all $\mathrm{K}_{\mathrm{h}}$ values greater than $10 \mathrm{ft} / \mathrm{d}$, and the $\mathrm{SB}$, $\mathrm{SN}, \mathrm{BP}$, and LP sites all had minimum $\mathrm{K}_{\mathrm{h}}$ values greater than $100 \mathrm{ft} / \mathrm{d}$. If the nonstreambed values were included, 12 of the sites had ranges in $\mathrm{K}_{\mathrm{h}}$ greater than 3 orders of magnitude (fig. 23B).

The profiles also allowed for similarities to be identified. The streambed $K_{h}$ profiles of the main-stem Platte River and South Platte River sites generally were more conductive than the other sites of the Platte River watershed by at least an order of magnitude (fig. 23A). The main-stem profiles varied little, with most values ranging between 100 and $1,000 \mathrm{ft} / \mathrm{d}$. Based on the definition of streambed type (fig. 2), these main-stem sites all had type $\mathrm{C}$ streambeds, where streambed materials did not limit GW/SW interaction. Additionally, the two Platte River tributary sites having type C streambeds (sites NM and PS) were in the flood plain of the North Platte and Platte Rivers, respectively. By contrast, the other three Platte River tributary sites (sites PC, BC, and WT) were out of the flood plain and had type B streambeds, where restrictive materials existed below the streambed surface. All of the sites tested in the Republican River watershed were tributaries that were out of the 

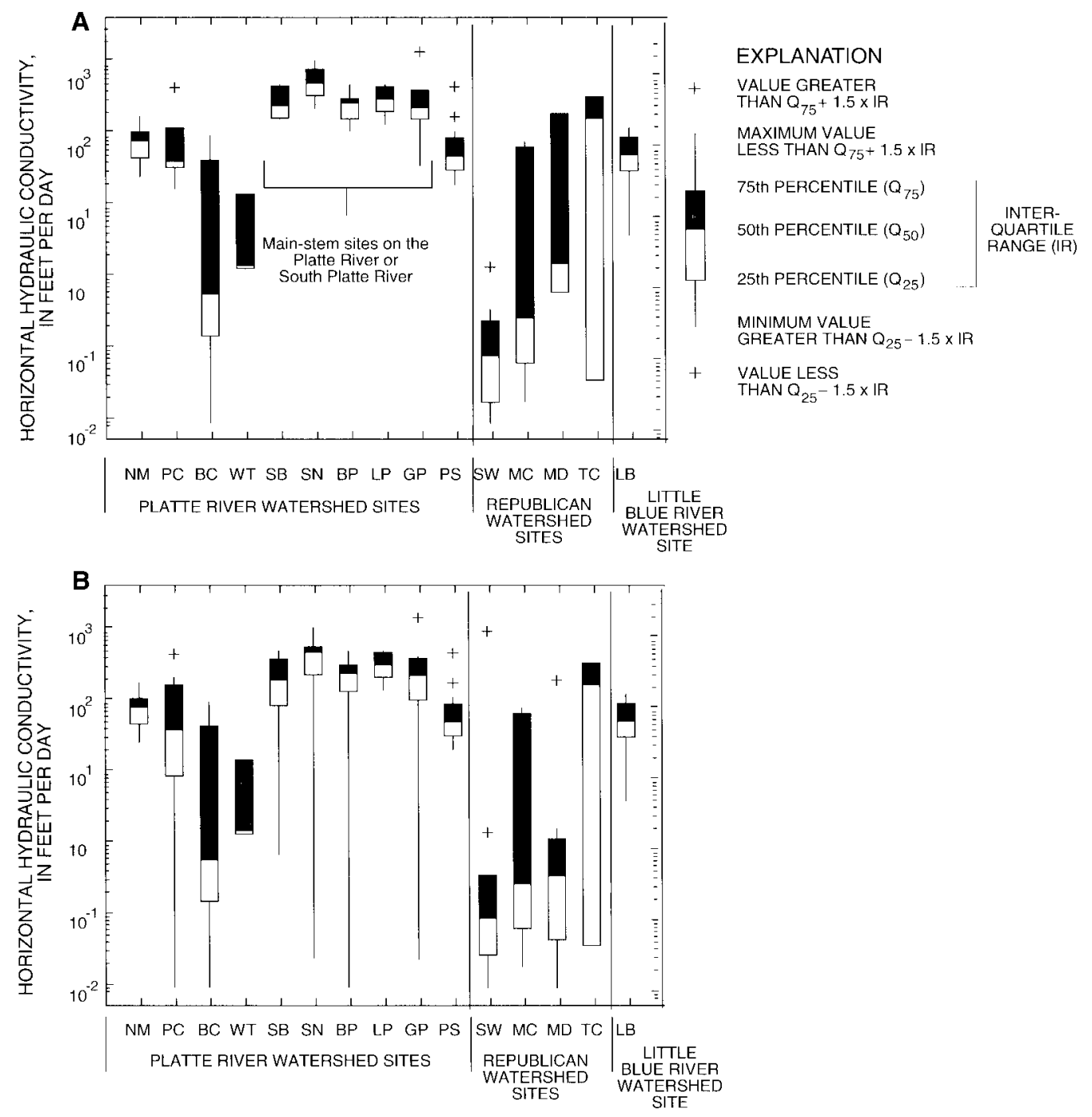

Figure 23. Isotropic horizontal hydraulic conductivity for each site using $(A)$ streambed measurements only and (B) all measurements.

Republican River flood plain and had type B streambeds, while the one site in the Little Blue River watershed was on the Little Blue River and had a type C streambed. Additionally, the streambed $\mathrm{K}$ for several type A streambeds in the study area, where restrictive materials existed at the streambed surface, are being evaluated using field permeameter methods as part of another study. These two data sets of streambed $\mathrm{K}$ can be used in various applications, including the modeling of GW/SW interactions in central and western Nebraska.

The variability observed in some profiles suggests that assuming a vertically uniform streambed $\mathrm{K}_{\mathrm{h}}$ value may be an oversimplification. However, when it is necessary to use one encompassing value, the harmonic mean may be the best representation of the hydraulically restrictive or conductive properties of several layers of materials (Freeze and Cherry, 1979). Knowledge of the variability in $\mathrm{K}_{\mathrm{h}}$ along a vertical profile can be useful in studies that consider streambed $\mathrm{K}$. The profiles constrain the values used in models of ground-water flow and surface-water flow and indicate the range of $\mathrm{K}$ values that may be determined.

Limitations to the interpretation of the profiles do exist. Although most studies require a spatial distribution of streambed $K$, the profiles represent point measurements. By comparing all of the profiles, similarities can be identified, such as in the case of the 
Platte and South Platte River sites. However, the true extent of spatial variability is still undefined. Additionally, the boundary between streambed and aquifer is only an estimation at the test sites and is completely unknown at untested sites, and variability in that boundary may be important. Finally, the anisotropy of the streambed materials cannot be defined from the slug-test procedure. Although the results incorporated estimated anisotropy ratios of 1 and 10 (based on the Zlotnik (1994) method), values given are measurements of the horizontal $\mathrm{K}$, whereas vertical $\mathrm{K}$ is more relevant to most GW/SW interaction. If layering documented by the bridge borehole logs is assumed to be representative of the area and large variability in the profiles corresponds to these layers, the presence of anisotropy may be presumed.

\section{SUMMARY}

Streambed hydraulic conductivity $(\mathrm{K})$ is one of the controlling factors for water fluxes across the stream/aquifer interface, and its representation in GW/SW interaction models is important to waterresources managers. However, in central and western Nebraska, this parameter is generally undefined. To understand the conductivity of streambeds in central and western Nebraska better, slug tests were performed at 15 stream sites and profiles of $K_{h}$ with depth were developed. Temporary wells were driven to predetermined depths using direct-push techniques, and slug tests were initiated using pneumatic or mechanical methods. The slug-test response data were monitored and recorded on site using a laptop computer, which was used to analyze the slug tests following each response. Responses that took longer than 30 seconds to recover were analyzed using the Bouwer and Rice method; all other tests were analyzed using the Springer and Gelhar method. Measurements of $\mathrm{K}_{\mathrm{h}}$ then were plotted against depth to create profiles of the streambed. These profiles appeared to be adequate representations of the streambed at the sites, based on comparison of multiple profiles at the BP site.

To separate the streambed $\mathrm{K}_{\mathrm{h}}$ measurements from that of nonstreambed materials for each profile, nearby lithologic descriptions from bridge boreholes and test holes were compared to the $\mathrm{K}_{\mathrm{h}}$ profile data, when available. At most sites, abrupt changes in the profile or contact with an impenetrable layer often could be correlated with lithologic changes, suggesting that the vertical extent of streambed materials may be estimated through the analysis of these boreholes.

The profiles and corresponding lithology showed a wide range in the streams tested and suggested that some streambeds display a large amount of variability in $\mathrm{K}_{\mathrm{h}}$ with depth. The Stinking Water Creek site had the profile with the smallest streambed $K_{h}$ values, which led to a harmonic mean of $0.03 \mathrm{ft} / \mathrm{d}$. A site on the South Platte River near North Platte had the profile with the largest streambed $K_{h}$ values, which resulted in a harmonic mean of $450 \mathrm{ft} / \mathrm{d}$. Seven of 15 sites had streambed values that ranged over more than 3 orders of magnitude, and that variability increased significantly when the measurements assumed to be from nonstreambed materials were included. Although using one value to represent streambed $\mathrm{K}$ for a given stream reach may be an oversimplification, the use of the harmonic mean of all values in the profile is suggested to assess the restrictive properties of layered materials.

Although the profiles only provide insight into streambed $\mathrm{K}_{\mathrm{h}}$ at a given point, similarities can be identified, such as the generally larger and more homogeneous $\mathrm{K}_{\mathrm{h}}$ values seen at the Platte and South Platte River sites compared to those from other sites. The study focused on streambeds where materials situated below the surface restricted GW/SW interaction (type B) and streambeds where no restrictive materials existed (type C). Of the sites tested, all of the type C streambeds were on the main stem or on tributaries situated on the flood plain of the main stem of the respective watershed, whereas all of the type B streambeds were on tributaries out of the main-stem flood plain.

In addition to providing site-specific information about streambeds, the streambed $\mathrm{K}$ dataset allows streambeds to be differentiated, which is useful to water-resources managers. When the streambed $\mathrm{K}$ data from the type A sites are added, this dataset should provide a representative sampling that improves understanding of GW/SW interaction in central and western Nebraska. 


\section{REFERENCES}

Bouwer, Herman, and Rice, R.C., 1976, A slug test for determining hydraulic conductivity of unconfined aquifers with completely or partially penetrating wells: Water Resources Research, v. 12, p. 423-428.

Butler, J.J., Jr., 1998, The design, performance, and analysis of slug tests: New York, Lewis Publishers, 252 p.

Cey, E.E., Rudolph, D.L., Parkin, G.W., and Aravena, Ramon, 1998, Quantifying groundwater discharge to a small perennial stream in southern Ontario, Canada: Journal of Hydrology, v. 210, p. 31-37.

Chen Xunhong, and Yin Yanfeng, 1999, Evaluation of streamflow depletion for vertical anisotropic aquifers: Journal of Environmental Systems, v. 27, no. 1, p. $55-70$.

Conrad, L.P., and Beljin, M.S., 1996, Evaluation of an induced infiltration model as applied to glacial aquifer systems: Water Resources Bulletin, v. 32, no. 6 , p. 1209-1220.

Cooperative Hydrology Study, Description of Cooperative Hydrology Study program: accessed May 30, 2001, at URL http://cohyst.nrc.state.ne.us/

Diffendal, R.F., Jr., and Goeke, J.W., 2000, Keith County test hole logs: University of Nebraska-Lincoln, Institute of Agriculture and Natural Resources, Conservation and Survey Division, $115 \mathrm{p}$.

Dreeszen, V.H., Reed, E.C., Burchett, R.R., and Prichard, G.E., 1973, Bedrock geologic map showing thickness of overlying Quaternary deposits, Grand Island quadrangle, Nebraska and Kansas: U.S. Geological Survey Miscellaneous Geologic Investigations Map I-819, scale $1: 250,000$.

Eversoll, D.A., 2000, Hayes County test hole logs: University of Nebraska-Lincoln, Institute of Agriculture and Natural Resources, Conservation and Survey Division, $56 \mathrm{p}$.

Eversoll, D.A., Dreeszen, V.H., Burchett, R.R., and Prichard, G.E., 1988, Bedrock geologic map showing the configuration of the bedrock surface, McCook $1^{\circ} \times 2^{\circ}$ quadrangle, Nebraska and Kansas, and part of the Sterling $1^{\circ} \times 2^{\circ}$ quadrangle, Nebraska and Colorado: U.S. Geological Survey Miscellaneous Investigations Series Map I-1878, scale 1:250,000.

Freeze, R.A., and Cherry, J.A., 1979, Groundwater: Englewood Cliffs, New Jersey, Prentice-Hall, Inc., 604 p.

Goeke, J.W., 2000, Lincoln County test hole logs: University of Nebraska-Lincoln, Institute of Agriculture and Natural Resources, Conservation and Survey Division, $185 \mathrm{p}$.

Hart, D.R., Mulholland, P.J., Marzolf, E.R., DeAngelis, D.L., and Hendricks, S.P., 1999, Relationships between hydraulic parameters in a small stream under varying flow and seasonal conditions: Hydrological Processes, v. 13, p. 1497-1510.

Harvey, J.W., and Bencala, K.E., 1993, The effect of streambed topography on surface-subsurface water exchange in mountain catchments: Water Resources Research, v. 29, no. 1, p. 89-98.

Hinsby, Klaus, Bjerg, P.L., Andersen, L.J., Skov, Bent, and Clausen, E.V., 1992, A mini-slug test method for determination of a local hydraulic conductivity of an unconfined sandy aquifer: Journal of Hydrology, v. 136, p. $87-106$.

Hunt, Bruce, 1999, Unsteady stream depletion from ground water pumping: Ground Water, v. 37, no. 1, p. 98-102.

Kircher, J.E., 1981, Sediment analyses for selected sites on the South Platte River in Colorado and Nebraska, and the North Platte and Platte Rivers in NebraskaSuspended sediment, bedload, and bed material: U.S. Geological Survey Open-File Report 81-207, $48 \mathrm{p}$.

Landon, M.K., Rus, D.L., and Harvey, F.E., in press, Comparison of instream methods for measuring hydraulic conductivity in sandy streambeds: Ground Water.

Larkin, R.G., and Sharp, J.M., 1992, On the relationship between river-basin geomorphology, aquifer hydraulics, and ground-water flow direction in alluvial aquifers: Geological Society of America Bulletin, v. 104, p. $1608-1620$.

Luckey, R.L., and Becker, M.F., 1999, Hydrogeology, water use, and simulation of flow in the High Plains aquifer in northwestern Oklahoma, southeastern Colorado, southwestern Kansas, northeastern New Mexico, and northwestern Texas: U.S. Geological Survey WaterResources Investigations Report 99-4104, 68 p.

McDonald, M.G., and Harbaugh, A.W., 1988, A modular three-dimensional finite-difference ground-water flow model: U.S. Geological Survey Techniques of WaterResources Investigations, book 6, chap. A 1 .

McMahon, P.B., Tindall, J.A., Collins, J.A., Hull, K.J., and Nuttle, J.R., 1995, Hydrologic and geochemical effects on oxygen uptake in bottom sediments of an effluentdominated river: Water Resources Research, v. 31 , no. 10 , p. $2561-2569$.

Petersen, T.A., Armstrong, D.S., Stark, J.R., and Hansen, D.S., 1995, Spatial variability of streambed properties related to stream-channel geomorphology and base flow of a gaining stream in glaciated north central Minnesota in Hotchkiss, W.R., Downey, J.S., Gutentag, E.D., and Moore, J.E., eds., Water Resources at Risk: Proceedings of AIH Conference, May 14-18, 1995, Denver, Colorado, American Institute of Hydrology, p. LL141-LL153. 
Rosenshein, J.S., 1988, Hydrology of North America, Region 18, Alluvial valleys, in Back, W., Rosenshein, J.S., and Seaber, P.R., eds., The geology of North America: Boulder, Colorado, Geological Society of North America, v. O-2, p. 165-176.

Sibray, S.S., and Smith, F.A., 2000, Scotts Bluff County test hole logs: University of Nebraska-Lincoln, Institute of Agriculture and Natural Resources, Conservation and Survey Division, $49 \mathrm{p}$.

Smith, F.A., 1999, Dawson County test hole logs: University of Nebraska-Lincoln, Institute of Agriculture and Natural Resources, Conservation and Survey Division, $119 \mathrm{p}$.

Smith, F.A., and Swinehart, J.B., 2000, Garden County test hole logs: University of Nebraska-Lincoln, Institute of Agriculture and Natural Resources, Conservation and Survey Division, $91 \mathrm{p}$.

Sophocleous, M.A., Koussis, A.D., Martin, J.L., and Perkins, S.P., 1995, Evaluation of simplified streamaquifer depletion models for water rights administration: Ground Water, v. 33, no. 4, p. 579-588.

Springer, R.K., and Gelhar, L.W., 1991, Characterization of large scale aquifer heterogeneity in glacial outwash by analysis of slug tests with oscillatory response, Cape Cod, Massachusetts, in Mallard, G.E., and Aronson, D.A., eds., U.S. Geological Survey Toxic Substances Hydrology Program, Proceedings of the Technical Meeting, Monterey, California, March 11-15, 1991: U.S. Geological Survey Water-Resources Investigations Report 91-4034, p. 36-40.

Swinehart, J.B., Dreeszen, V.H., Richmond, G.M., Tipton, M.J., Bretz, Richard, Steece, F.V., Hallberg, G.R., and Goebel, J.E., 1994, Quaternary geologic map of the Platte River $4^{\circ} \times 6^{\circ}$ quadrangle, United States: U.S. Geological Survey Miscellaneous Investigations Series Map I-1420 (NK-14), scale 1:1,000,000.

Taylor, K.C., Wheatcraft, S.W., Hess, John, Hayworth, J.S., and Molz, F.J., 1990, Evaluation of methods of determining the vertical distribution of hydraulic conductivity: Ground Water, v. 28: no. 1, p. 88-98.

Todd, D.K., 1980, Groundwater hydrology (2d ed.): New York, Wiley and Sons, 535 p. van der Kamp, Garth, 1976, Determining aquifer transmissivity by means of well response tests-The underdamped case: Water Resources Research, v. 12, no. 1, p. 71-77.

Verstraeten, I.M., Sibray, S.S., Cannia, J.C., and Tanner, D.Q., 1995, Reconnaissance of ground-water quality in the North Platte Natural Resources District, western Nebraska, June-July 1991: U.S. Geological Survey Water-Resources Investigations Report 94-4057, $114 \mathrm{p}$.

Waite, H.A., Reed, E.C., and Jones, D.S., Jr., 1946, Ground water in the Republican River Basin in Nebraska: University of Nebraska-Lincoln, Conservation and Survey Division, Nebraska Water Resources Survey Water-Supply Paper 1, 38 p.

Yu, Zhongbo, and Schwartz, F.W., 1999, Automated calibration applied to watershed-scale flow simulations: Hydrological Processes, v. 13, p. 191-209.

Zlotnik, V.A., 1994, Interpretation of slug and packer tests in anisotropic aquifers: Ground Water, v. 32, no. 5, p. 761-766.

Zlotnik, V.A., and Huang, Huihua, 1999, Effect of partial penetration and streambed sediments on aquifer response to stream stage fluctuations: Ground Water, v. 37, no. 4, p. 599-605.

Zlotnik, V.A., and McGuire, V.L., 1998, Multi-level slug tests in highly permeable formations-1. Modification of the Springer-Gelhar (SG) model: Journal of Hydrology, v. 204, p. 271-282.

Zlotnik, V.A., Zurbuchen, B.R., Ptak, Thomas, and Teutsch, Georg, 2000, Support volume and scale effect in hydraulic conductivity-Experimental aspects, in Zhang, Dongxiao, and Winter, C.L., eds., Theory, modeling, and field investigation in hydrogeology-A special volume in honor of Shlomo P. Neuman's 60th birthday: Boulder, Colo., Geological Society of America Special Paper 348, p. 215-231.

Zurbuchen, B.R., Zlotnik, V.A., and Butler, J.J., Jr., in press, Dynamic interpretation of slug tests in highly permeable aquifers: Water Resources Research. 
Rosenshein, J.S., 1988, Hydrology of North America, Region 18, Alluvial valleys, in Back, W., Rosenshein, J.S., and Seaber, P.R., eds., The geology of North America: Boulder, Colorado, Geological Society of North America, v. O-2, p. 165-176.

Sibray, S.S., and Smith, F.A., 2000, Scotts Bluff County test hole logs: University of Nebraska-Lincoln, Institute of Agriculture and Natural Resources, Conservation and Survey Division, $49 \mathrm{p}$.

Smith, F.A., 1999, Dawson County test hole logs: University of Nebraska-Lincoln, Institute of Agriculture and Natural Resources, Conservation and Survey Division, $119 \mathrm{p}$.

Smith, F.A., and Swinehart, J.B., 2000, Garden County test hole logs: University of Nebraska-Lincoln, Institute of Agriculture and Natural Resources, Conservation and Survey Division, $91 \mathrm{p}$.

Sophocleous, M.A., Koussis, A.D., Martin, J.L., and Perkins, S.P., 1995, Evaluation of simplified streamaquifer depletion models for water rights administration: Ground Water, v. 33, no. 4, p. 579-588.

Springer, R.K., and Gelhar, L.W., 1991, Characterization of large scale aquifer heterogeneity in glacial outwash by analysis of slug tests with oscillatory response, Cape Cod, Massachusetts, in Mallard, G.E., and Aronson, D.A., eds., U.S. Geological Survey Toxic Substances Hydrology Program, Proceedings of the Technical Meeting, Monterey, California, March 11-15, 1991: U.S. Geological Survey Water-Resources Investigations Report 91-4034, p. 36-40.

Swinehart, J.B., Dreeszen, V.H., Richmond, G.M., Tipton, M.J., Bretz, Richard, Steece, F.V., Hallberg, G.R., and Goebel, J.E., 1994, Quaternary geologic map of the Platte River $4^{\circ} \times 6^{\circ}$ quadrangle, United States: U.S. Geological Survey Miscellaneous Investigations Series Map I-1420 (NK-14), scale 1:1,000,000.

Taylor, K.C., Wheatcraft, S.W., Hess, John, Hayworth, J.S., and Molz, F.J., 1990, Evaluation of methods of determining the vertical distribution of hydraulic conductivity: Ground Water, v. 28: no. 1, p. 88-98.

Todd, D.K., 1980, Groundwater hydrology (2d ed.): New York, Wiley and Sons, $535 \mathrm{p}$. van der Kamp, Garth, 1976, Determining aquifer transmissivity by means of well response tests-The underdamped case: Water Resources Research, v. 12, no. 1, p. 71-77.

Verstraeten, I.M., Sibray, S.S., Cannia, J.C., and Tanner, D.Q., 1995, Reconnaissance of ground-water quality in the North Platte Natural Resources District, western Nebraska, June-July 1991: U.S. Geological Survey Water-Resources Investigations Report 94-4057, $114 \mathrm{p}$.

Waite, H.A., Reed, E.C., and Jones, D.S., Jr., 1946, Ground water in the Republican River Basin in Nebraska: University of Nebraska-Lincoln, Conservation and Survey Division, Nebraska Water Resources Survey Water-Supply Paper 1, 38 p.

Yu, Zhongbo, and Schwartz, F.W., 1999, Automated calibration applied to watershed-scale flow simulations: Hydrological Processes, v. 13, p. 191-209.

Zlotnik, V.A., 1994, Interpretation of slug and packer tests in anisotropic aquifers: Ground Water, v. 32, no. 5, p. 761-766.

Zlotnik, V.A., and Huang, Huihua, 1999, Effect of partial penetration and streambed sediments on aquifer response to stream stage fluctuations: Ground Water, v. 37, no. 4, p. 599-605.

Zlotnik, V.A., and McGuire, V.L., 1998, Multi-level slug tests in highly permeable formations-1. Modification of the Springer-Gelhar (SG) model: Journal of Hydrology, v. 204, p. 271-282.

Zlotnik, V.A., Zurbuchen, B.R., Ptak, Thomas, and Teutsch, Georg, 2000, Support volume and scale effect in hydraulic conductivity-Experimental aspects, in Zhang, Dongxiao, and Winter, C.L., eds., Theory, modeling, and field investigation in hydrogeology-A special volume in honor of Shlomo P. Neuman's 60th birthday: Boulder, Colo., Geological Society of America Special Paper 348, p. 215-231.

Zurbuchen, B.R., Zlotnik, V.A., and Butler, J.J., Jr., in press, Dynamic interpretation of slug tests in highly permeable aquifers: Water Resources Research. 
Appendix. Individual measurements of streambed hydraulic conductivity

[MOS, middle of screen; ft, feet; $\mathrm{K}_{\mathrm{h}}$, horizontal hydraulic conductivity; - iso, isotropic conditions assumed; ft/d, feet per day; -aniso, anisotropic conditions (anisotropy ratio of 10) assumed; OOM, orders of magnitude; Site abbreviations given in table 1; --, not applicable; Y, yes; $\mathrm{N}$, no; $<$, less than

\begin{tabular}{|c|c|c|c|c|c|}
\hline Site & $\begin{array}{c}\text { Depth to MOS } \\
\text { (ft) }\end{array}$ & $\begin{array}{l}K_{h-i s o} \\
(\mathrm{ft} / \mathrm{d})\end{array}$ & $\begin{array}{c}\mathrm{K}_{\mathrm{h} \text {-aniso }} \\
(\mathrm{ft} / \mathrm{d})\end{array}$ & $\begin{array}{c}\text { Uncertainty } \\
\text { factor } \\
\text { (OOM) }\end{array}$ & $\begin{array}{c}\text { Streambed } \\
\text { materials } \\
(\mathrm{Y} / \mathrm{N})\end{array}$ \\
\hline $\mathrm{NM}$ & 1.8 & 180 & 320 & -- & $\mathrm{Y}$ \\
\hline $\mathrm{NM}$ & 3.8 & 27 & 45 & \pm 0.2 & $\mathrm{Y}$ \\
\hline $\mathrm{NM}$ & 5.9 & 170 & 290 & -- & $\mathrm{Y}$ \\
\hline $\mathrm{NM}$ & 7.8 & 83 & 140 & -- & $\mathrm{Y}$ \\
\hline $\mathrm{NM}$ & 9.8 & 99 & 170 & -- & $\mathrm{Y}$ \\
\hline $\mathrm{NM}$ & 12 & 61 & 100 & -- & Y \\
\hline NM & 14 & 72 & 120 & -- & Y \\
\hline NM & 16 & 110 & 200 & -- & $\mathrm{Y}$ \\
\hline NM & 18 & 110 & 200 & -- & $\mathrm{Y}$ \\
\hline NM & 20 & 48 & 84 & -- & $\mathrm{Y}$ \\
\hline $\mathrm{NM}$ & 21 & 45 & 76 & -- & Y \\
\hline $\mathrm{PC}$ & 2.6 & 460 & 790 & \pm 0.2 & $\mathrm{Y}$ \\
\hline $\mathrm{PC}$ & 4.7 & 18 & 29 & -- & Y \\
\hline $\mathrm{PC}$ & 6.7 & 36 & 57 & -- & $\mathrm{Y}$ \\
\hline $\mathrm{PC}$ & 8.8 & 130 & 210 & -- & $\mathrm{Y}$ \\
\hline $\mathrm{PC}$ & 11 & 44 & 69 & -- & $\mathrm{Y}$ \\
\hline $\mathrm{PC}$ & 13 & $<0.01$ & $<0.01$ & -- & $\mathrm{N}$ \\
\hline $\mathrm{PC}$ & 15 & 220 & 330 & \pm 0.2 & $\mathrm{~N}$ \\
\hline $\mathrm{PC}$ & 17 & $<0.01$ & $<0.01$ & -- & $\mathrm{N}$ \\
\hline $\mathrm{BC}$ & 1.6 & 99 & 170 & -- & $\mathrm{Y}$ \\
\hline $\mathrm{BC}$ & 3.9 & 69 & 120 & -- & $\mathrm{Y}$ \\
\hline $\mathrm{BC}$ & 5.7 & 45 & 76 & -- & $\mathrm{Y}$ \\
\hline $\mathrm{BC}$ & 7.7 & $<0.01$ & $<0.01$ & -- & Y \\
\hline $\mathrm{BC}$ & 9.7 & 0.65 & 1.1 & \pm 0.2 & Y \\
\hline $\mathrm{BC}$ & 12 & 1.9 & 3.1 & -- & Y \\
\hline $\mathrm{BC}$ & 14 & 0.29 & 0.48 & -- & $\mathrm{Y}$ \\
\hline $\mathrm{BC}$ & 16 & $<0.01$ & $<0.01$ & -- & $\mathrm{Y}$ \\
\hline $\mathrm{BC}$ & 18 & 0.16 & 0.27 & \pm 0.4 & $Y$ \\
\hline $\mathrm{BC}$ & 20 & 0.57 & 0.96 & -- & $\mathrm{Y}$ \\
\hline WT & 1.6 & 15 & 24 & -- & $\mathrm{Y}$ \\
\hline WT & 3.6 & 1.4 & 2.2 & - & $\mathrm{Y}$ \\
\hline WT & 5.1 & 1.6 & 2.5 & -- & $\mathrm{Y}$ \\
\hline SB & 1.6 & 490 & 790 & -- & $\mathrm{Y}$ \\
\hline $\mathrm{SB}$ & 3.5 & 170 & 280 & -- & $\mathrm{Y}$ \\
\hline $\mathrm{SB}$ & 5.4 & 520 & 850 & \pm 0.2 & $\mathrm{Y}$ \\
\hline SB & 7.4 & 300 & 490 & -- & $\mathrm{Y}$ \\
\hline SB & 9.4 & 220 & 360 & -- & $\mathrm{Y}$ \\
\hline SB & 11 & 180 & 280 & -- & $\mathrm{Y}$ \\
\hline $\mathrm{SB}$ & 13 & 7.1 & 11 & \pm 0.2 & $\mathrm{~N}$ \\
\hline SB & 15 & 0.73 & 1.1 & - & $\mathrm{N}$ \\
\hline
\end{tabular}


Appendix. Individual measurements of streambed hydraulic conductivity-Continued

[MOS, middle of screen; fl, feet; $\mathrm{K}_{\mathrm{h}}$, horizontal hydraulic conductivity; -iso, isotropic conditions assumed: fl/d, feet per day; -aniso, anisotropic conditions (anisotropy ratio of 10 ) assumed; OOM, orders of magnitude; Site abbreviations given in table 1; --, not applicable: Y, yes; N. no; <, less than|

\begin{tabular}{|c|c|c|c|c|c|}
\hline Site & $\begin{array}{l}\text { Depth to MOS } \\
\text { (ft) }\end{array}$ & $\begin{array}{l}K_{h-i s o} \\
\text { (ft/d) }\end{array}$ & $\begin{array}{c}\mathrm{K}_{\mathrm{h}-\text { aniso }} \\
\text { (ft/d) }\end{array}$ & $\begin{array}{c}\text { Uncertainty } \\
\text { factor } \\
\text { (OOM) }\end{array}$ & $\begin{array}{c}\text { Streambed } \\
\text { materials } \\
(\mathrm{Y} / \mathrm{N})\end{array}$ \\
\hline $\mathrm{SN}$ & 1.5 & 490 & 820 & -- & $\bar{Y}$ \\
\hline SN & 3.7 & 590 & 920 & \pm 0.2 & $\mathrm{Y}$ \\
\hline $\mathrm{SN}$ & 5.5 & 1,100 & 1,700 & \pm 0.2 & $Y$ \\
\hline $\mathrm{SN}$ & 7.6 & 240 & 390 & -- & $\mathrm{Y}$ \\
\hline $\mathrm{SN}$ & 9.5 & 0.026 & 0.04 & -- & $N$ \\
\hline $\mathrm{BP}^{\mathrm{l}}$ & 2 & 360 & 620 & -- & $\mathrm{Y}$ \\
\hline $\mathrm{BP}^{\mathrm{l}}$ & 3.9 & 150 & 250 & -- & Y \\
\hline $\mathrm{BP}^{\mathrm{l}}$ & 5.9 & 170 & 290 & -- & Y \\
\hline $\mathrm{BP}^{!}$ & 7.9 & 290 & 460 & -- & Y \\
\hline $\mathrm{BP}^{1}$ & 9.9 & 320 & 520 & -- & $\mathrm{Y}$ \\
\hline $\mathrm{BP}^{\mathrm{l}}$ & 12 & 140 & 230 & -- & $\mathrm{Y}$ \\
\hline $\mathrm{BP}^{\mathrm{l}}$ & 14 & 520 & 850 & \pm 0.2 & $\mathrm{Y}$ \\
\hline $\mathrm{BP}^{1}$ & 16 & 4.6 & 7.2 & -- & $\mathrm{N}$ \\
\hline $\mathrm{BP}^{1}$ & 18 & 0.01 & 0.016 & \pm 0.2 & $\mathrm{~N}$ \\
\hline $\mathrm{BP}^{2}$ & 1.6 & 330 & 560 & -- & $Y$ \\
\hline $\mathrm{BP}^{2}$ & 3.6 & 250 & 430 & -- & Y \\
\hline $\mathrm{BP}^{2}$ & 5.7 & 220 & 360 & -. & $\mathrm{Y}$ \\
\hline $\mathrm{BP}^{2}$ & 7.7 & 330 & 560 & \pm 0.2 & $\mathrm{Y}$ \\
\hline $\mathrm{BP}^{2}$ & 9.7 & 390 & 620 & -- & $\mathrm{Y}$ \\
\hline $\mathrm{BP}^{2}$ & 12 & 120 & 190 & -- & $\mathrm{Y}$ \\
\hline $\mathrm{BP}^{2}$ & 14 & 290 & 460 & -- & $\mathrm{Y}$ \\
\hline $\mathrm{BP}^{2}$ & 16 & 0.048 & 0.074 & -- & $\mathrm{N}$ \\
\hline LP & 1.6 & 490 & 820 & -- & $Y$ \\
\hline LP & 3.5 & 430 & 720 & -- & $Y$ \\
\hline LP & 5.5 & 150 & 250 & -- & $\mathrm{Y}$ \\
\hline LP & 7.5 & 490 & 850 & -- & Y \\
\hline LP & 9.6 & 520 & 890 & -- & Y \\
\hline LP & 12 & 460 & 790 & -- & $Y$ \\
\hline LP & 13 & 220 & 380 & -- & Y \\
\hline LP & 15 & 210 & 360 & -- & $\mathrm{Y}$ \\
\hline LP & 17 & 290 & 490 & -- & $Y$ \\
\hline LP & 19 & 320 & 560 & -- & $Y$ \\
\hline LP & 21 & 330 & 590 & -- & Y \\
\hline GP & 1.6 & 220 & 370 & -- & $\mathrm{Y}$ \\
\hline GP & 3.6 & 1.500 & 2,500 & \pm 0.2 & $\mathrm{Y}$ \\
\hline GP & 5.6 & 430 & 690 & -- & Y \\
\hline GP & 7.6 & 250 & 390 & -- & Y \\
\hline GP & 9.6 & 170 & 280 & -- & $\mathrm{Y}$ \\
\hline GP & 12 & 390 & 620 & -- & $\mathrm{Y}$ \\
\hline GP & 14 & 39 & 65 & -- & $\mathrm{Y}$ \\
\hline GP & 16 & 0.025 & 0.039 & \pm 0.4 & $\mathrm{~N}$ \\
\hline
\end{tabular}


Appendix. Individual measurements of streambed hydraulic conductivity-Continued

[MOS, middle of screen; ft, feet; $\mathrm{K}_{\mathrm{h}}$, horizontal hydraulic conductivity; _iso, isotropic conditions assumed; ft/d, feet per day; -aniso- anisotropic conditions (anisotropy ratio of 10) assumed; OOM. orders of magnitude; Site abbreviations given in table 1; --, not applicable; Y, yes;

$\mathrm{N}$, no; $<$, less than]

\begin{tabular}{|c|c|c|c|c|c|}
\hline Site & $\begin{array}{c}\text { Depth to MOS } \\
\text { (ft) }\end{array}$ & $\begin{array}{l}K_{h-i s o} \\
(f t / d)\end{array}$ & $\begin{array}{c}K_{\mathbf{h}-a n i s o} \\
\text { (ft/d) }\end{array}$ & $\begin{array}{l}\text { Uncertainty } \\
\text { factor } \\
\text { (OOM) }\end{array}$ & $\begin{array}{c}\text { Streambed } \\
\text { materials } \\
(\mathrm{Y} / \mathrm{N})\end{array}$ \\
\hline PS & 1.6 & 78 & 130 & -- & $\bar{Y}$ \\
\hline PS & 2.3 & 95 & 160 & -- & $\mathrm{Y}$ \\
\hline PS & 3.3 & 50 & 85 & -- & $\mathrm{Y}$ \\
\hline PS & 4.2 & 37 & 63 & -- & $\mathrm{Y}$ \\
\hline PS & 5.2 & 25 & 42 & -- & $Y$ \\
\hline PS & 6.1 & 47 & 78 & -- & $\mathrm{Y}$ \\
\hline PS & 7.4 & 74 & 120 & -- & $\mathrm{Y}$ \\
\hline PS & 8.5 & 34 & 59 & -- & $\mathrm{Y}$ \\
\hline PS & 9.4 & 21 & 36 & -- & $\mathrm{Y}$ \\
\hline PS & 10 & 22 & 37 & -- & $\mathrm{Y}$ \\
\hline PS & 12 & 56 & 92 & -- & $\mathrm{Y}$ \\
\hline PS & 14 & 490 & 790 & \pm 0.2 & $\mathrm{Y}$ \\
\hline PS & 16 & 120 & 190 & -- & $\mathrm{Y}$ \\
\hline PS & 18 & 190 & 300 & -- & $\mathrm{Y}$ \\
\hline PS & 20 & 53 & 86 & -- & $\mathrm{Y}$ \\
\hline SW & 2.7 & 0.38 & 0.64 & \pm 0.2 & $Y$ \\
\hline SW & 4.5 & 0.079 & 0.13 & \pm 0.4 & $\mathrm{Y}$ \\
\hline SW & 6.5 & $<0.01$ & $<0.01$ & -- & $Y$ \\
\hline SW & 8.4 & 0.029 & 0.049 & \pm 0.2 & $\mathrm{Y}$ \\
\hline SW & 10 & 1.5 & 2.5 & -- & $\mathrm{Y}$ \\
\hline $\mathrm{SW}$ & 12 & 0.094 & 0.16 & \pm 0.4 & $Y$ \\
\hline $\mathrm{SW}$ & 14 & $<0.01$ & $<0.01$ & -- & $\mathrm{Y}$ \\
\hline SW & 18 & 0.15 & 0.26 & \pm 0.4 & $\mathrm{Y}$ \\
\hline SW & 20 & 1,000 & 1,700 & \pm 0.2 & $\mathrm{~N}$ \\
\hline $\mathrm{MC}$ & 1.6 & 70 & 110 & -- & $\mathrm{Y}$ \\
\hline $\mathrm{MC}$ & 3.6 & 0.18 & 0.29 & \pm 0.2 & $\mathrm{Y}$ \\
\hline $\mathrm{MC}$ & 5.5 & 0.02 & 0.031 & \pm 0.4 & $Y$ \\
\hline $\mathrm{MC}$ & 7.4 & 57 & 91 & -- & $\mathrm{Y}$ \\
\hline $\mathrm{MC}$ & 9.5 & 84 & 130 & -- & $\mathrm{Y}$ \\
\hline $\mathrm{MC}$ & 11 & 0.29 & 0.41 & \pm 0.2 & $Y$ \\
\hline $\mathrm{MC}$ & 12 & 0.069 & 0.11 & \pm 0.4 & $Y$ \\
\hline $\mathrm{MD}$ & 1.6 & 210 & 340 & -- & Y \\
\hline $\mathrm{MD}$ & 3.6 & 1.7 & 2.7 & -- & $\mathrm{Y}$ \\
\hline $\mathrm{MD}$ & 5.7 & 0.67 & 1.1 & \pm 0.2 & $\mathrm{Y}$ \\
\hline $\mathrm{MD}$ & 7.5 & 0.05 & 0.079 & \pm 0.4 & $\mathrm{~N}$ \\
\hline MD & 9.4 & 0.75 & 1.2 & - & $\mathrm{N}$ \\
\hline MD & 11 & $<0.01$ & $<0.01$ & -- & $\mathrm{N}$ \\
\hline $\mathrm{MD}$ & 13 & 0.08 & 0.13 & \pm 0.4 & $\mathrm{~N}$ \\
\hline MD & 15 & 0.046 & 0.071 & \pm 0.4 & $\mathrm{~N}$ \\
\hline
\end{tabular}


Appendix. Individual measurements of streambed hydraulic conductivity-Continued

[MOS, middle of screen; ft, feet; $\mathrm{K}_{\mathrm{h}}$. horizontal hydraulic conductivity; ${ }_{\text {iso }}$, isotropic conditions assumed; ft/d, feet per day; - -uniso, anisotropic conditions (anisotropy ratio of 10) assumed; OOM, orders of magnitude; Site abbreviations given in table 1; --, not applicable; Y, yes;

$\mathrm{N}$, no; $<$, less than]

\begin{tabular}{|c|c|c|c|c|c|}
\hline Site & $\begin{array}{l}\text { Depth to MOS } \\
\text { (ft) }\end{array}$ & $\begin{array}{l}K_{h-i s o} \\
(\mathrm{ft} / \mathrm{d})\end{array}$ & $\begin{array}{c}\mathrm{K}_{\mathrm{h}-\text { aniso }} \\
\text { (ft/d) }\end{array}$ & $\begin{array}{l}\text { Uncertainty } \\
\text { factor } \\
\text { (OOM) }\end{array}$ & $\begin{array}{c}\text { Streambed } \\
\text { materials } \\
(\mathrm{Y} / \mathrm{N})\end{array}$ \\
\hline TC & 1.6 & 360 & 590 & -- & $\mathrm{Y}$ \\
\hline $\mathrm{TC}$ & 3.3 & 0.04 & 0.063 & \pm 0.2 & $\mathrm{Y}$ \\
\hline LB & 1.7 & 80 & 130 & -- & $\mathrm{Y}$ \\
\hline LB & 3.6 & 79 & 130 & -- & $\mathrm{Y}$ \\
\hline LB & 5.6 & 40 & 66 & -- & $Y$ \\
\hline $\mathrm{LB}$ & 7.6 & 56 & 94 & -- & $\mathrm{Y}$ \\
\hline LB & 9.6 & 34 & 56 & -- & $Y$ \\
\hline LB & 12 & 20 & 33 & -- & Y \\
\hline $\mathrm{LB}$ & 13 & 34 & 56 & -- & $Y$ \\
\hline LB & 15 & 98 & 170 & -- & $Y$ \\
\hline LB & 17 & 4.2 & 7.1 & -- & $\mathrm{Y}$ \\
\hline LB & 19 & 120 & 200 & -- & $Y$ \\
\hline LB & 21 & 130 & 230 & -- & $Y$ \\
\hline
\end{tabular}

IEstimates from slug-test hole number 1 .

'Estimates from slug-test hole number 2 . 